\title{
Geomechanical modelling of Paleozoic Shale Gas Formation: a case study from the Baltic Basin, northern Poland
}

\author{
Małgorzata Słota-Valim ${ }^{1}$, Krzysztof Sowiżdża1', Halina Jędrzejowska-Tyczkowska ${ }^{2}$ \\ ${ }^{1}$ INiG-PIB Oil and Gas Institute - National Reasearch Institute, Department of Geology and Geochemistry; \\ ul.Lubicz 25A, 31-503 Krakow, Poland; e-mail: slota@inig.pl, sowizdzal@inig.pl \\ ${ }^{2}$ INiG-BIP Oil and Gas Institute - National Reasearch Institute, Department of Seismics; \\ ul. Lubicz 25A, 31-503 Krakow, Poland; e-mail: tyczkowska@inig.pl
}

(C) 2017 Authors. This is an open access publication, which can be used, distributed and reproduced in any medium according to the Creative Commons CC-BY 4.0 License requiring that the original work has been properly cited.

Received: 11 September 2017; accepted: 11 December 2017

\begin{abstract}
The article presents the importance and position of geomechanical modelling workflow in reservoir characterization studies dedicated to unconventional shale reservoirs. We show the results of 3D geomechanical modelling carried out in an onshore area within the Baltic Basin, northern Poland, where the Silurian and Ordovician shale formations are the exploration targets. The fundamental elements of the methodology, processes, and available datasets used in the modelling are discussed. The petrophysical, elastic, and mechanic properties of the rock were applied in the modelling process, along with the principal stresses and pore pressure in the geological formation. Moreover, the main calculation methods and data requirements for the Mechanical Earth Model construction are discussed. A comprehensive 3D geomechanical model was constructed, providing important information to engineers and decision makers which allows them to optimize well placement, the direction of the horizontal section of the borehole and the parameters of hydraulic fracturing treatment. The model can identify zones of higher potential within the area of interest in terms of efficient stimulation treatment design.
\end{abstract}

Keywords: Mechanical Earth Model, geomechanics, elastic properties, strength parameters, principal stresses

\section{INTRODUCTION}

Reservoir characterization studies carried out for unconventional shale reservoirs include analysis, modelling and interpretation of much wider range of geological formations' properties. Apart from those considered for conventional reservoirs such as porosity, permeability, shale content, and hydrocarbons saturation, shale reservoirs also require profound reconnaissance of mineralogical composition, organic matter (TOC) as well as geomechanical properties (Romero \& Philp 2012, Bruyelle \& Guérillot 2014, Heege et al. 2015). The latter determine parameters essential for stimulation treatment of unconventional shale formation.
Mechanical modelling has become a powerful tool, especially in challenging reservoir situations such as unconventional shale or tight sandstone formations. Such settings usually require reservoir rock to be stimulated by hydraulic fracturing to initiate and sustain gas flow from the shale formations into the wellbore. Stimulation treatments attempt to recreate natural fracture networks and/or generate artificial fractures that become the path for gas flow (King 2012). The fracturing efficiency strongly depends on understanding the stress regime as well as the mechanical properties of the rock (Fjaer 2008, Bjørlykke 2010, Zoback 2010); therefore, geomechanical 3D modeling may provide a tool that not only helps optimize horizontal 
well trajectory paths and stimulation treatment design (Plumb et al. 2000), but also allows the identification of areas more suitable for treatment, i.e. where more efficient rock drainage can be achieved (Akbar et al. 2008). The application of geomechanics and numerical 3D modeling, along with the spatial visualization of the reservoir properties, can help decision-makers avoid and/or reduce problems and risks during the various stages of exploration and development of unconventional reservoirs (Slatt 2010, Herwanger \& Koutsabeloulis 2011).

This paper presents the results of a 3D geomechanical modeling case study carried out using a dataset of an onshore area within the Baltic Basin, where Silurian and Ordovician shale formations are the exploration targets; the fundamental elements of the methods, processes, and the dataset are discussed. The modeling incorporates parameters that represent the physical properties of the rock (petrophysical, elastic, and mechanic) and the principal stresses and pore pressure in the geological formation. The main calculation methods and data requirements for establishing the Mechanical Earth Model (MEM) are also discussed. The mechanical properties of the overburden and surrounding rocks are investigated, allowing for the complete construction of the Lower Paleozoic shale formation MEM. The comprehensive 3D geomechanical model presented in this study can help geo-engineers to identify zones within the area of interest of higher potential in terms of efficient stimulation treatment design (Zou 2013).

\section{GEOLOGICAL SETTING}

The study was carried out on Lower Paleozoic shale formations located in the onshore part of the Baltic Basin (northern Poland). Over the past few years, shales in Poland have been the subject of intensive research, in the hope of finding hydrocarbon accumulations in this unconventional formation.

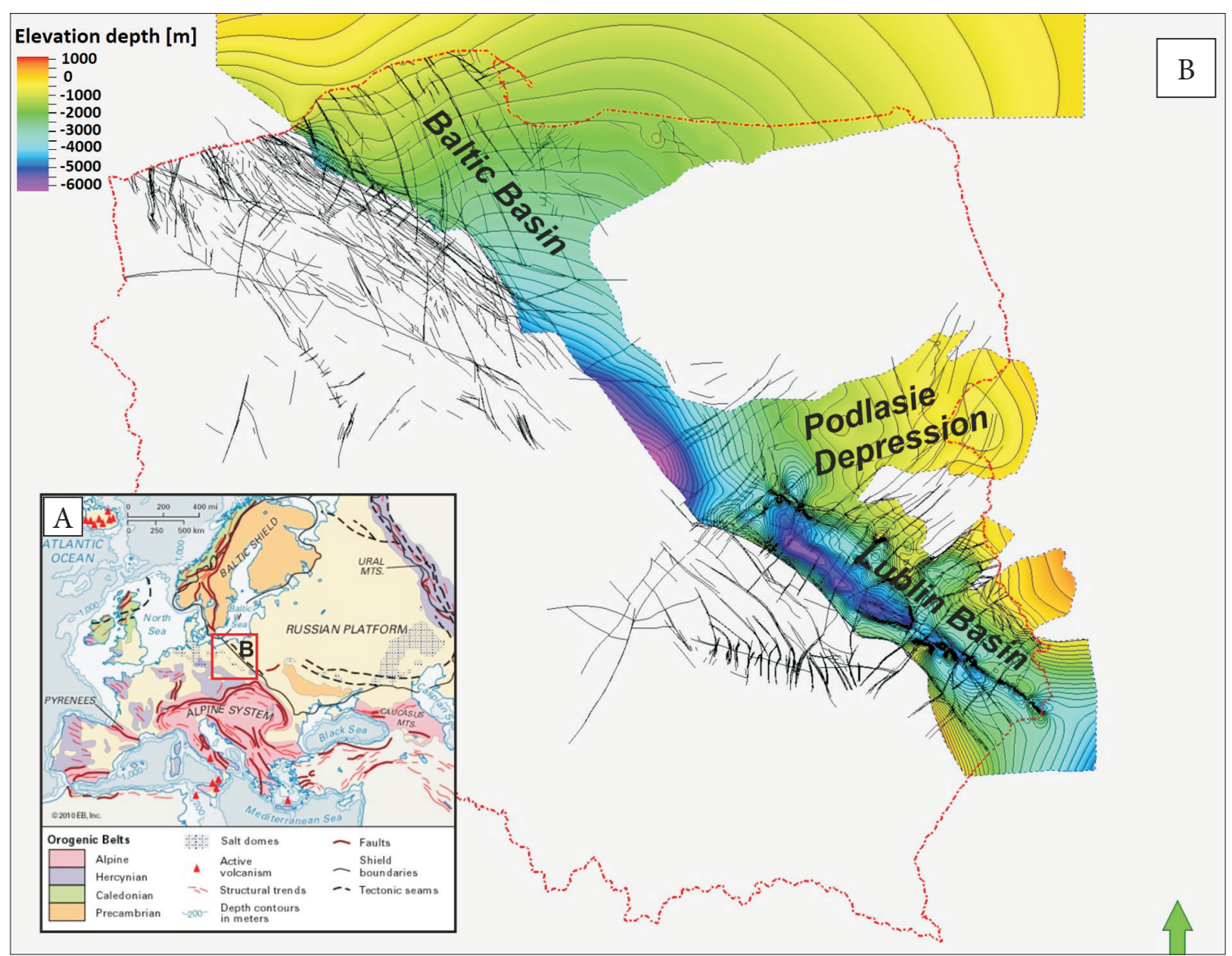

Fig. 1. Location of the Baltic Basin in Europe (A) (www.britannica.com) and enlarged map of Poland showing the depth of the top of the Paleozoic shale formation (B) 
The area of potential shale gas accumulation, encompassing approximately $37000 \mathrm{~km}^{2}$, stretches from northern Pomerania through the centraleastern regions of Poland and eastwards to Lublin (Geological characteristics of the basin, 2012). Shales of Ordovician and Silurian age, enriched in organic matter, were deposited along the western margin of the ancient continent of Baltica on the East European Platform within one basin, developed as a flexural foreland basin, during the Silurian collision of Baltica and eastern Avalonia (middle Caradoc to early middle Ashgill) (Vecoli \& Samuelsson 2003). The Baltic Basin, next to Podlasie, and the Lublin Basin were formed by the division of the main basin in later tectonic movements (local uplifts) and the erosion of sediments in the tectonically affected areas, which determined the spatial boundaries between these subbasins (Verniers et al. 2008). The burial depth of shales with hydrocarbon potential in the Polish part of the Baltic Basin increases generally from the east from a depth of $\sim 1000 \mathrm{~m}$ to more than $4500 \mathrm{~m}$ in the west (Poprawa 2010) The structural map of Lower Paleozoic shale formations in the Baltic, Podlasie and Lublin basins is presented in Figure 1.

\section{GEOMECHANICAL MODEL}

In the study, geomechanical modeling was performed using a combination of two Schlumberger software packages: Petrel RG 2014 for modeling the structural and reservoir properties of the study area and the geomechanical simulator Visage for geomechanical modeling.

\section{Model geometry}

The structural model of the lower Paleozoic shale formation consists of a layer of approximately 1000-m-thick sediments of Middle and Upper Cambrian, Ordovician, and Silurian (Llandovery, Wenlock, Ludlow) formations. Based on the total organic carbon content measurements from drill cores, six shale layers were identified (Shale $0,1,2$, 3, 3 BIS, and 4). The structural model constructed for the geomechanical and petrophysical modeling includes the six shale intervals and the formations that separate them (see Fig. 2). The model extends $11.77 \mathrm{~km}$ from east to west and $12.75 \mathrm{~km}$ from north to south. The horizontal resolution of the block model was set to $100 \mathrm{~m} \times 100 \mathrm{~m}$, while the vertical resolution varied depending on the zone thickness, importance, and model purpose.

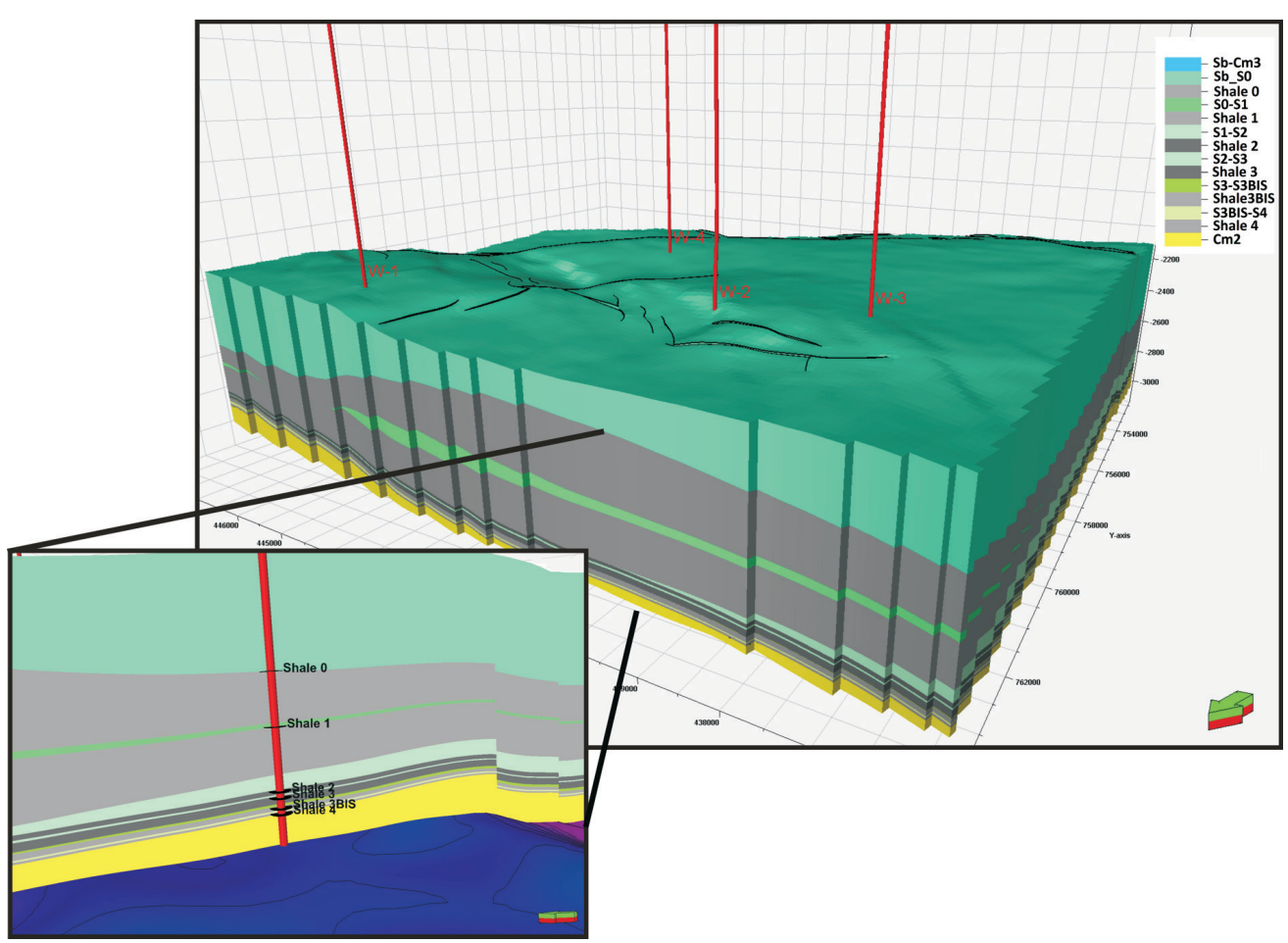

Fig. 2. Structural model of Paleozoic shale formations with an enlarged column showing the shale intervals identified from cores in the study area 


\section{Embedding}

The final geometry of the geological formations included in the geomechanical Visage model was determined by embedding the geological model with volumes of rocks. To avoid boundary effects, the shale formation was surrounded with underburden, sideburden, and overburden; thus, the final dimensions of the embedded model were 1:1:0.3 for the length, width, and height, respectively. The width of the final model corresponded to $109 \mathrm{~km}$ from east to west and $113 \mathrm{~km}$ north to south.

\section{Parametric models}

Certain information is required for the geomechanical model. This includes the spatial distribution of the rock's petrophysical parameters such as porosity $\phi$ and density $\rho$, the mechanical properties of rocks with unconfined compressive strength (UCS), elastic properties such as Young's modulus $E$ and Poisson's ratio $v$, and the distribution of stresses (vertical stress $\sigma_{v}$, minimum and maximum horizontal stresses $\sigma_{h}$ and $\sigma_{H}$, respectively) and pore pressure $P_{p}$.

In rock mechanics, assuming geological medium homogeneity, a number of parameters are used to characterize the rock formation and its behavior under applied stresses and pressure. The main ones are Young's modulus $E$, Poisson's ratio $v$, UCS, and the friction angle (FA).

Five boreholes were drilled in the study area; datasets from three of them were available for this study. Well logs and seismic data were used, the results of simultaneous inversion in the form of longitudinal and shear velocities as well as acoustic impedance cubes (Seismic Survey Report 2013). These were used to determine the petrophysical, elastic, and strength properties of the rock for the MEM.

\section{Petrophysical parameters}

Bulk density. Understanding the spatial variability of the bulk density of the rock is necessary to calculate overburden stress - one of the three principal stresses. The bulk density of the rock is determined through the analysis of core samples and geophysical wellbore logging methods. Rock density information can also be inferred from seismic inversion results. We used the results of simultaneous inversion (Seismic Survey Report 2013) which included the P-wave acoustic impedance (AI) and P-wave velocity $\left(v_{p}\right)$ cubes. The quotient of these two properties defines the spatial trend of the bulk density variability $(\rho)$ :

$\rho=\frac{A I}{v_{p}}$

In Figure 3, we show the procedure used to obtain bulk density.

To construct the MEM of the shale formation, the inversion results were integrated with well log-derived density data, which reflects more accurately the actual bulk density of the rock in the wellbores as well as its variability in the vertical direction. Bulk density profiles were available from three boreholes: W-1, W-2, and W-3. The aim of the integration process is to obtain maximum information from well data while taking advantage of the spatial nature of the information (such as spatial anisotropy characteristics) contained in the seismic-derived rock density cubes.

Correlation analysis of the well- and seismicderived rock density values was conducted for the boreholes for which both data sources were available. The correlation coefficient $R$ for the entire shale interval was 0.63. In Figure 4, we show the result of correlation between well- and seismicderived density on the crossplot.

To obtain more reliable estimates of the 3D bulk density distribution, both well log and seismic data were used simultaneously in $3 \mathrm{D}$ geostatistical modeling utilizing the co-kriging technique (Pyrcz \& Deutsch 2014). The investigation of the relationship between the well log and seismic data was preceded by averaging the high-resolution well-log data into the units (grid cells) of the vertical resolution of the model through the upscaling process. The seismic data (seismic attributes, inversion results, and a combination of both) were then re sampled, so that each block of the $3 \mathrm{D}$ model was assigned the averaged value of a seismically derived parameter from the SEG-Y file.

The spatial distribution of the bulk density in the shale formation model is shown in Figure 5.

Total porosity. The primary source of the data used to evaluate the spatial variability of the porosity was well data, direct laboratory measurements, and relatively reliable well logging interpretation. 


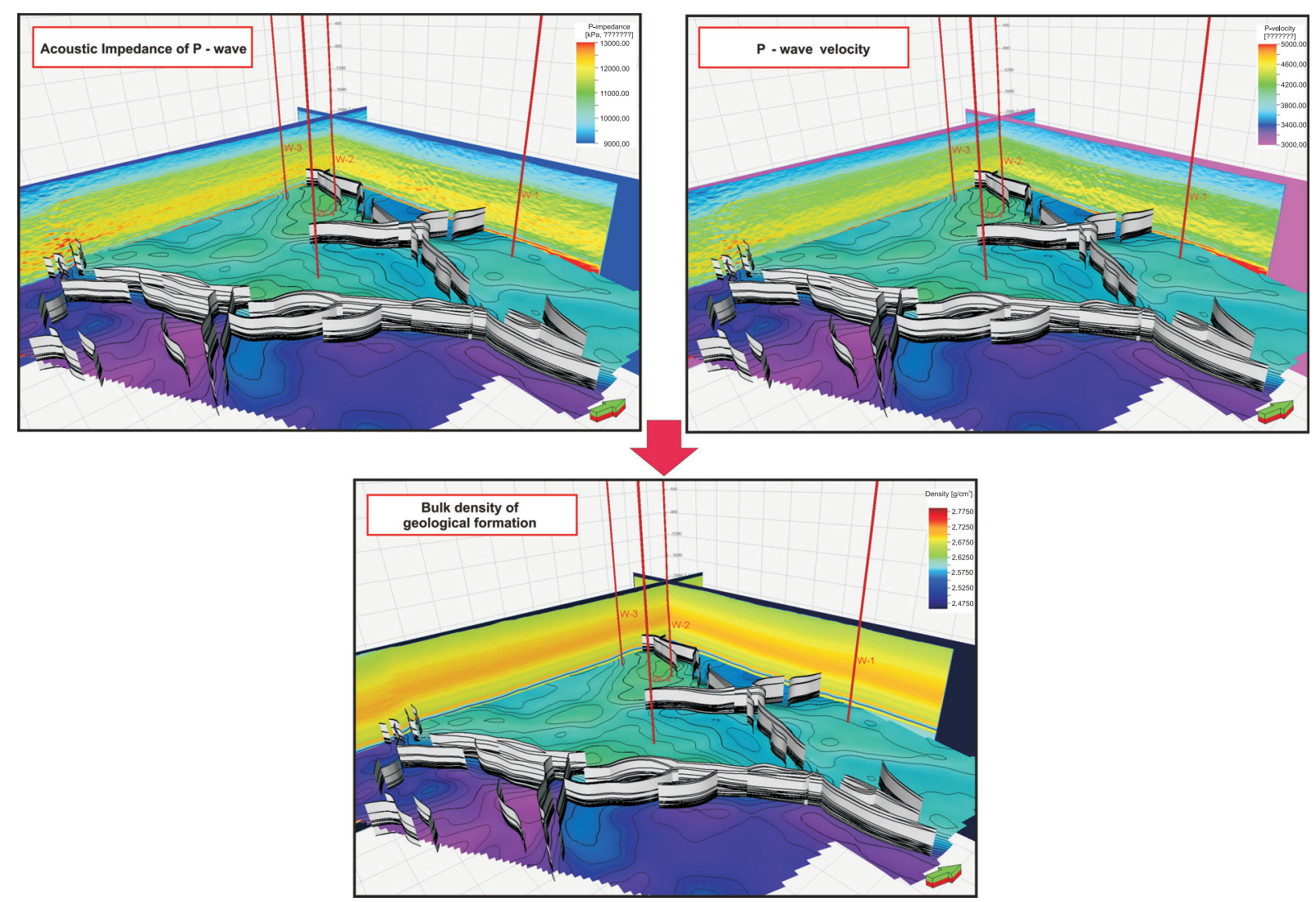

Fig. 3. Illustration of the procedure used for bulk density $3 D$ trend calculation based on the results of simultaneous seismic inversion

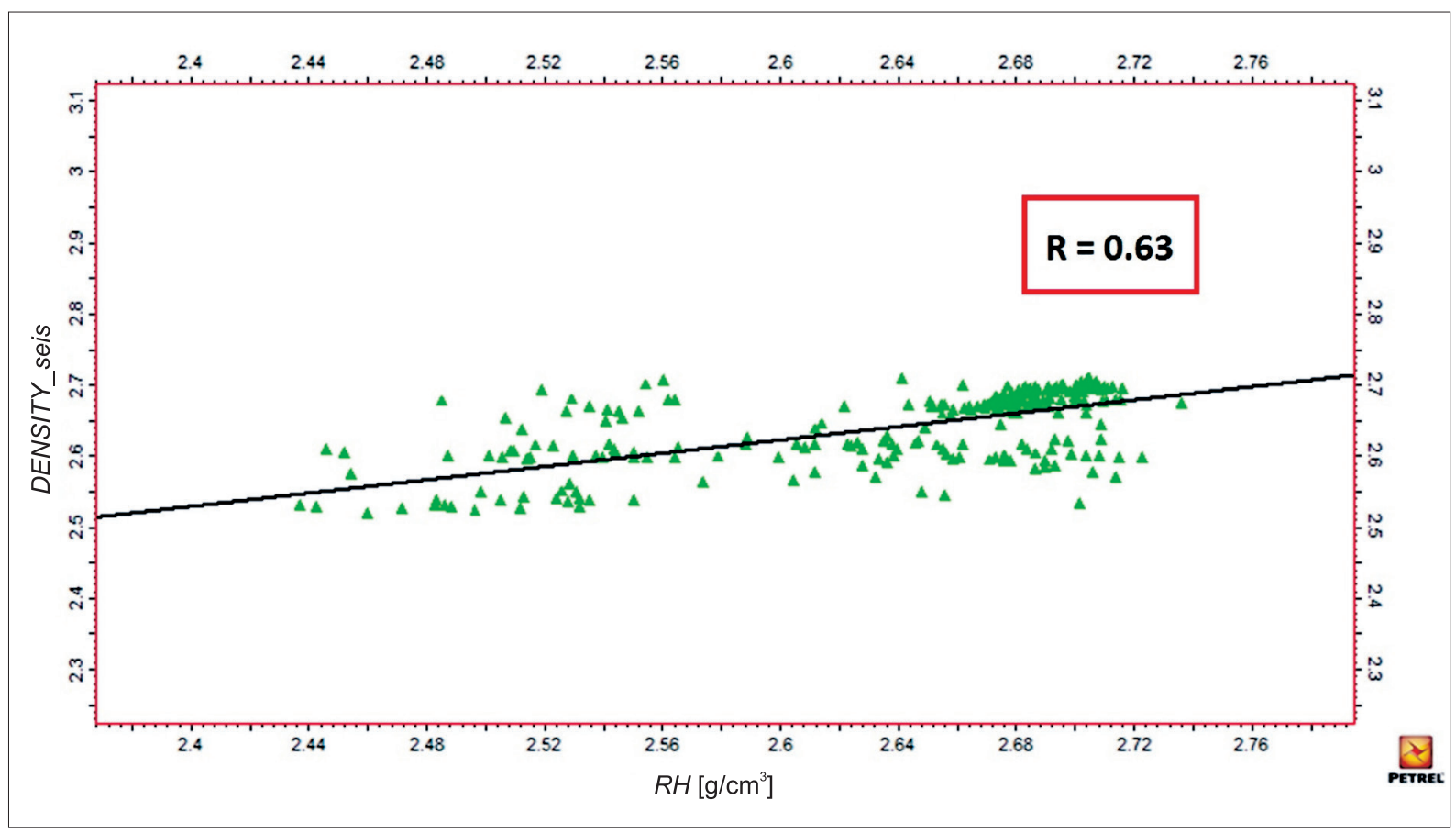

Fig. 4. Cross-correlation of the density measured in boreholes $(R H)$ and the density derived from seismic data (DENSITY_seis) 


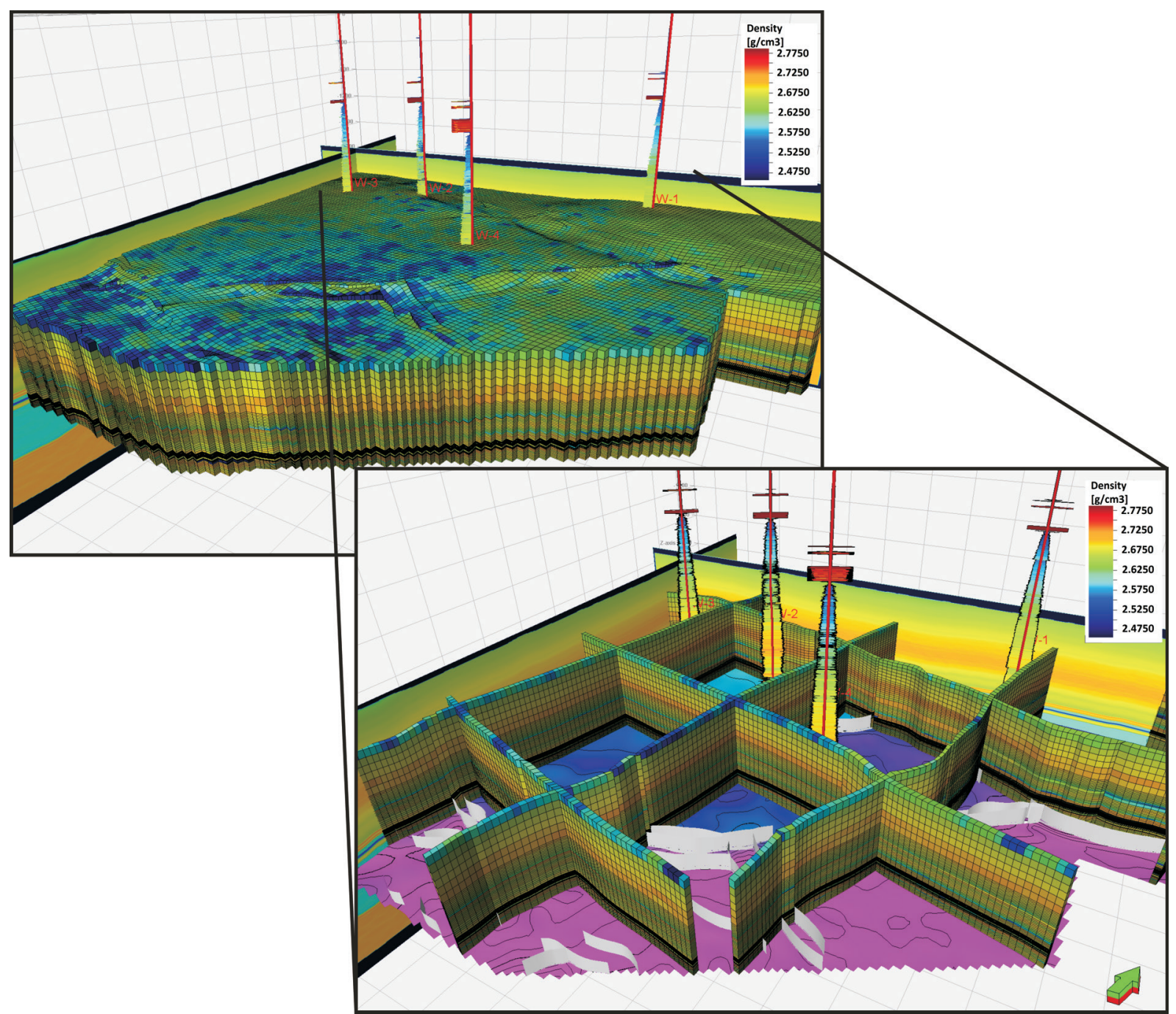

Fig. 5. 3D model of the bulk density in the shale formation; also shown are the bulk density borehole profiles in wells $W-1, W-2$, and $W-3$

As only three well log datasets were available, the available porosity data may not be a good representation of the porosity in the whole study area; therefore, a significant uncertainty in the total porosity distribution should be accounted for. To estimate the spatial distribution of the total porosity, seismic data that offers full coverage of the area of interest were used as an indirect source of information.

Geo statistical data analysis was performed to define the range and character of the data (histogram shape) as well as anisotropy orientation and intensity. Well data was used to define the porosity range and distribution as well as determine the theoretical model of the variogram and the range of the experimental semivariogram in the vertical direction.

To assign the parameters of the horizontal variogram and for the interpolation processes, 3D seismic data was used. Due to the moderate correlation between the porosity and individual seismic attributes, we attempted to transform several seismic properties (attributes and inversion results) into seismic meta-attributes of the porosity which have a higher correlation coefficient $R$ with the wellbore-derived porosity values, which can be observed in Figure 6 (Jędrzejowska-Tyczkowska 2003, Sowiżdżał 2012).

The above-mentioned seismic meta-attributes were used as a secondary variable while modeling the $3 \mathrm{D}$ distribution of the porosity using a stochastic algorithm. For further analysis we used the $3 \mathrm{D}$ porosity distribution - an arithmetic average of a certain number of realizations. In Figure 7, we show the 3D distribution of the final total porosity. 


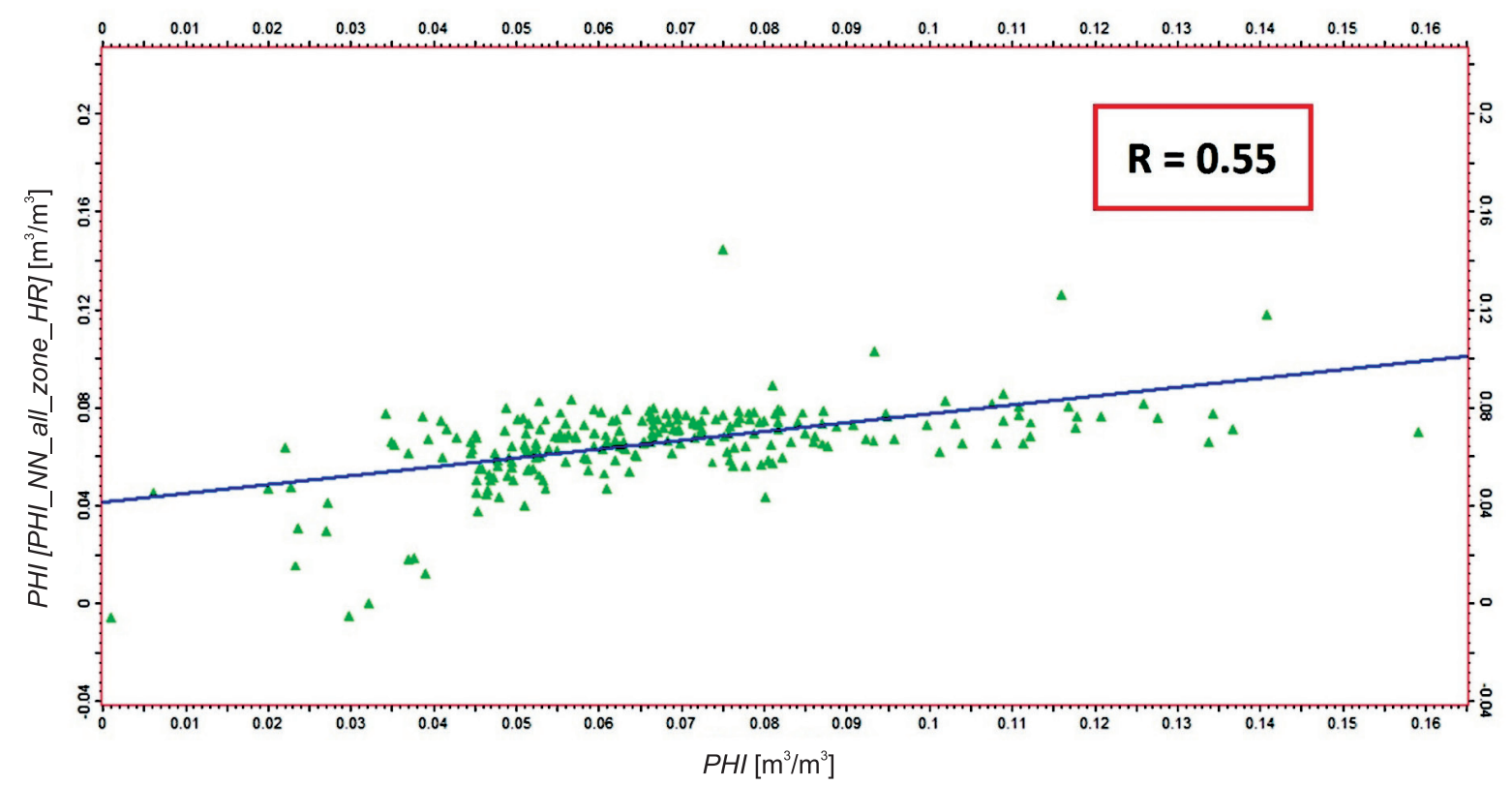

Fig. 6. The relationship between the total porosity (PHI) and seismic meta-attributes (PHI_NN) (based on seismic attributes) for the study area in the $3 D$ model

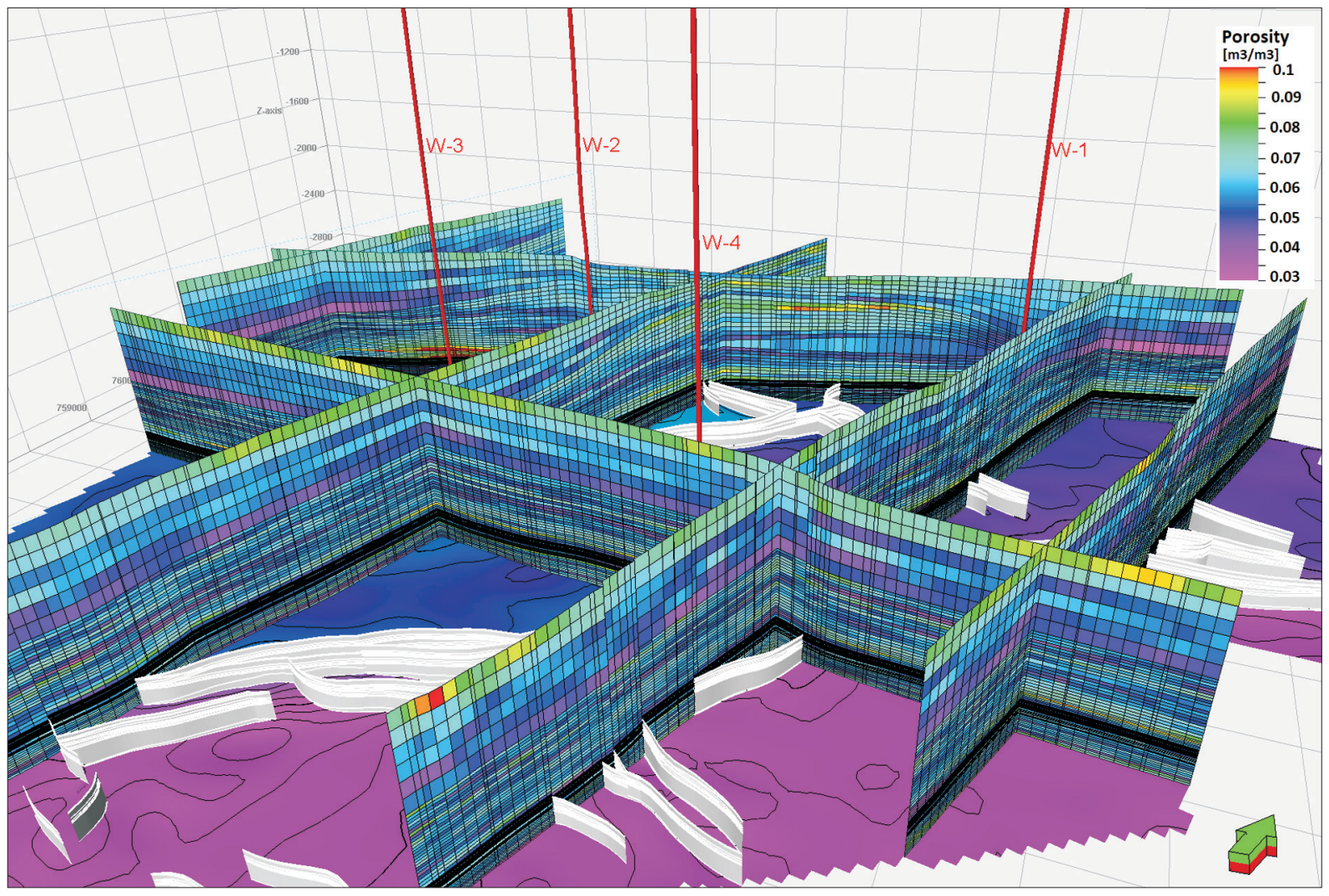

Fig. 7. 3D porosity model of the shale formations

\section{Elastic properties}

Elastic properties play an important role in geomechanical analyses as they describe the relationship between stress and the resulting deformation of the rock. The fundamental elastic parameters are Young's modulus $E$ and Poisson's ratio $v$, which describe the brittle/ductile character of the reservoir rock subjected to fracking (Akbar et al. 2008, Bjørlykke et al. 2010, Slatt 2011). The dynamic 
elastic properties $E$ and $v$ were calculated for the seismic cube O-3D, according to the relationships known from the literature (Jarosiński et al. 2006, Jędrzejowska-Tyczkowska \& Słota-Valim 2012) based on the results of simultaneous inversion in the form of acoustic impedance and P- and $\mathrm{S}$-wave velocity cubes. In Figure 8, we display the distribution of the average Young's modulus and Poisson's ratio in the most perspective shale formation Shale 2 and Shale 3, visualized with the structural map of the bottom of respective shale interval.

Static versus dynamic elastic properties. The derived elastic properties exhibit differences dependent on the measurement method. This phenomenon must be taken into account, especially in case of the further use of the elastic parameters to build a MEM and in advanced geomechanical evaluation (Herwanger \& Koutsabeloulis 2011). The empirically derived difference between the static and dynamic elastic parameters (i.e. the recorded velocity) can be explained by the difference in the frequency and strain amplitude during the measurements of these parameters (Mashinskii 2003, Fjær 2008, Słota-Valim 2015).

The construction of the MEM requires the calculation of the static elastic properties for the correct rock deformation analysis. The dynamic elastic properties can be transformed into static properties with the use of simple correlation functions or more advanced statistical tools, i.e. artificial intelligence. These methods aim at capturing the relationship between the properties recorded by acoustic log measurements and core tests.

Conversion method from dynamic to static elastic properties - the genetic algorithm. Genetic inversion combines elements of artificial neural networks, and aims to provide a reliable result in the form of the spatial distribution of the predicted parameter. Based on a neuron cell model, the genetic algorithm propagates the error backwards to update weights used by the Artificial Neural Network (Cordon \& van Hoogstraten 1995, Kowalska-Włodarczyk \& Darłak 2011).
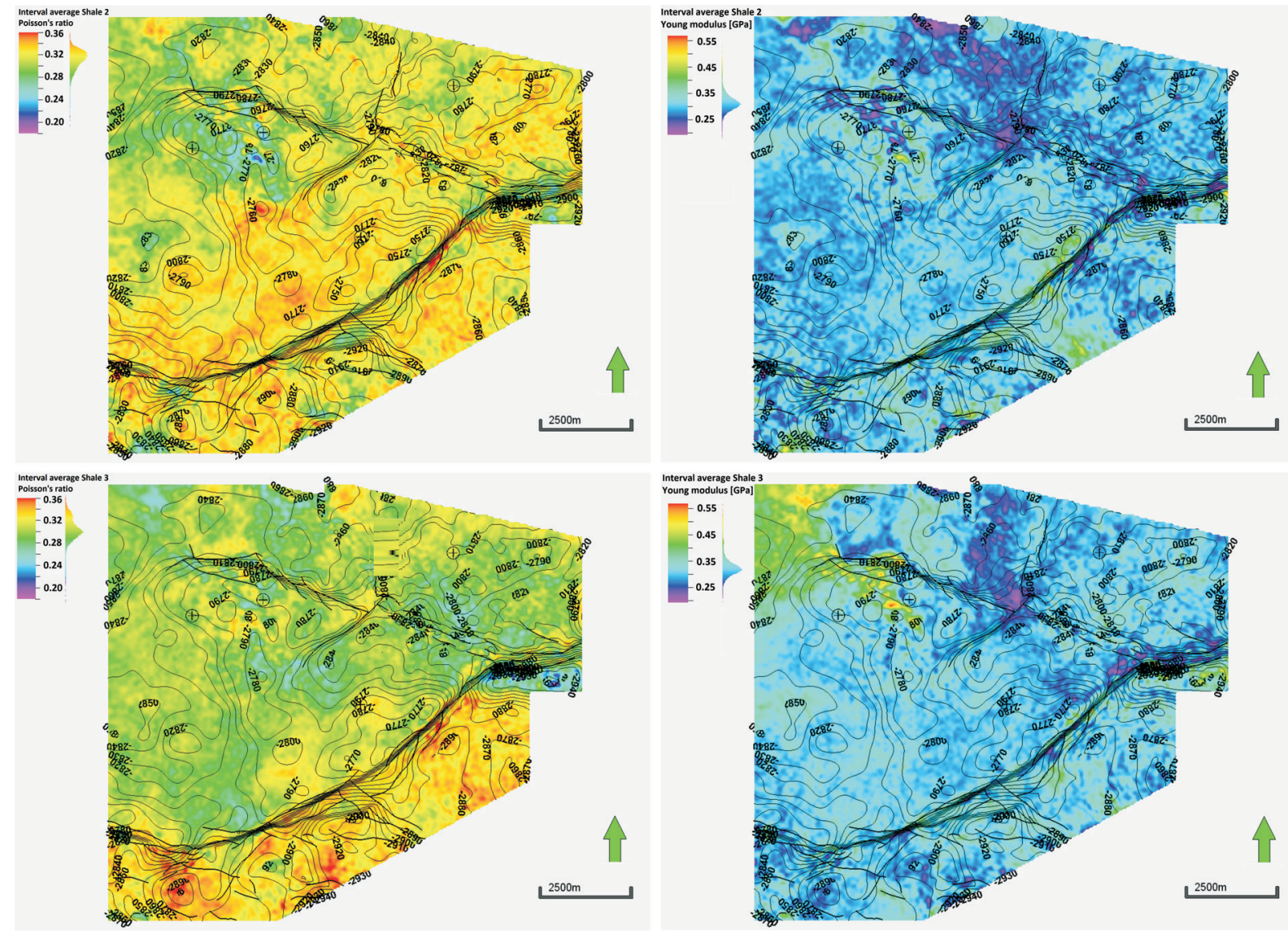

Fig. 8. Visualization of the average dynamic Poisson's ratio (left column) and Young's modulus (right column) calculated based on seismic inversion results, displaying the bottom surfaces of the Shale 2 (upper raw) and Shale 3 (lower raw) interval 
Genetic inversion can be used to predict parameters that are directly or indirectly related to the amplitude of seismic waves as well as estimating attributes derived from the recorded seismic signal, i.e. the density, velocity, porosity, and elastic properties of the rock. The genetic inversion procedure produces a non-linear operator used to convert the entire seismic volume into an estimated property described by the input data, used at the stage of neural network learning.

To estimate the distribution of the static elastic properties such as $E$ and $v$ the genetic inversion algorithm was used in two runs. In the first run, the correlation between the results of the acoustic measurements preformed in the seismic survey and those in the borehole was found and used to calculate the seismic cube, which was then applied in the second run to find the relationship with the static measurements data. Finally, the cubes of the static elastic properties were calculated.

The spatial distribution of the static Young's modulus $(E)$ and Poisson's ratio $(v)$ values are presented in Figure 9A and B, respectively.

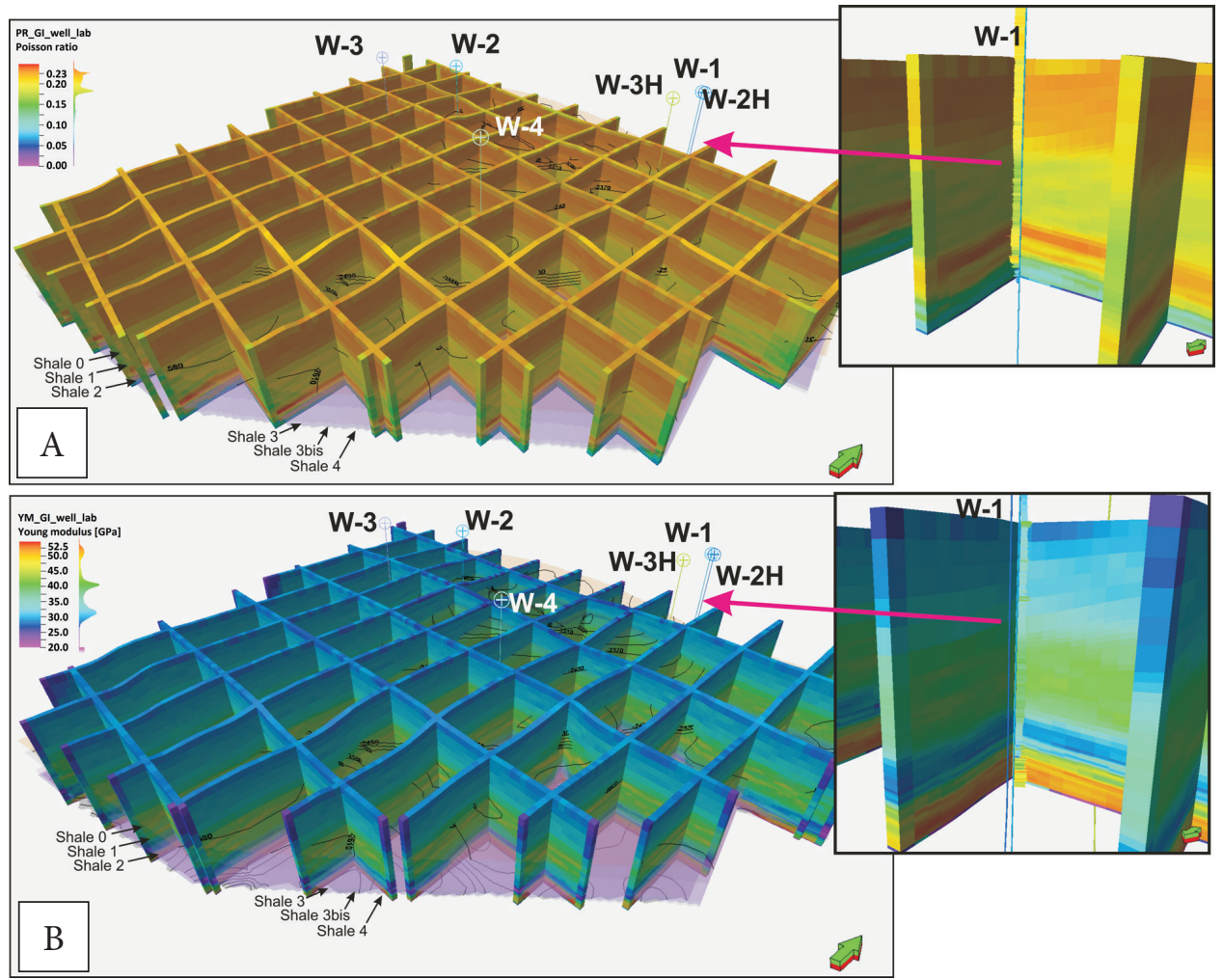

Fig. 9. Spatial distribution of static Poisson's ratio $v$ (A) Young's modulus E (B) and calculated from seismic data and well logs and converted into static values using a genetic algorithm. The enlarged images show the area near wellbore W-1 with the static elastic property log

\section{Strength parameters (Unconfined Compressive Strenght)}

Unconfined compressive strength (UCS) is one of the principal parameters used in geomechanical analysis. Due to the destructive nature of the measurement and its cost, statistical methods are more commonly used to estimate UCS based on the physical properties recorded in the wellbore or in seismic surveys (Butel et al. 2014). Thus, a continuous representation of the desired parameter describing the mechanical properties of the rock can be obtained.
To construct the MEM we used 63 results of strength measurement under uniaxial compression carried out on shale core samples from borehole $\mathrm{W}-1$. The results of the uniaxial compression tests were compared with parameters that may be correlated with the UCS. These parameters were: porosity, P-wave velocity, and Poisson's ratio (Chang et al. 2006). To estimate the UCS, the modeled total porosity, P-wave velocity resulting from simultaneous inversion, and the dynamic Poisson's ratio were calculated again based on the simultaneous inversion results. Prior to estimating 
statistically the relationships between the mentioned parameters, the UCS measurement log was up-scaled and the P-wave velocity, total porosity, and Poisson's ratio resampled to obtain the same resolution in all the compared parameters.

To investigate the spatial distribution of UCS, an Artificial Neural Network (ANN) was used. An ANN is a structure composed of tightly interconnected smaller components (artificial neurons), capable of performing computing processes in parallel. Neural networks have the ability to learn on the basis of available patterns derived from a sufficiently large amount of datasets. When an adequate amount of datasets are available, neural networks seek out relationships and establish patterns between the output and the input of the datasets (Cordon \& van Hoogstraten 1995). It is a tool used to determine the values of parameters inherently dependent on several variables of known value. With this tool it is possible to predict the values of parameters for which measurements are impossible or unviable (Sonmez et al. 2006).

To apply the artificial intelligence method to the 3D model, prior to the training of ANN, the P-wave velocity and Poisson's ratio data were resampled to the grid so that each block was assigned the average value of the parameter. The neural network learning process was carried out using three input parameters: porosity, P-wave velocity, and Poisson's ratio based on test results of $63 \mathrm{sam}$ ples from borehole W-1 under uniaxial compression. The relationships between these parameters and the UCS have correlation coefficients of 0.362 , 0.296 , and 0.484 for porosity, P-wave velocity, and Poisson's ratio, respectively (Fig. 10).
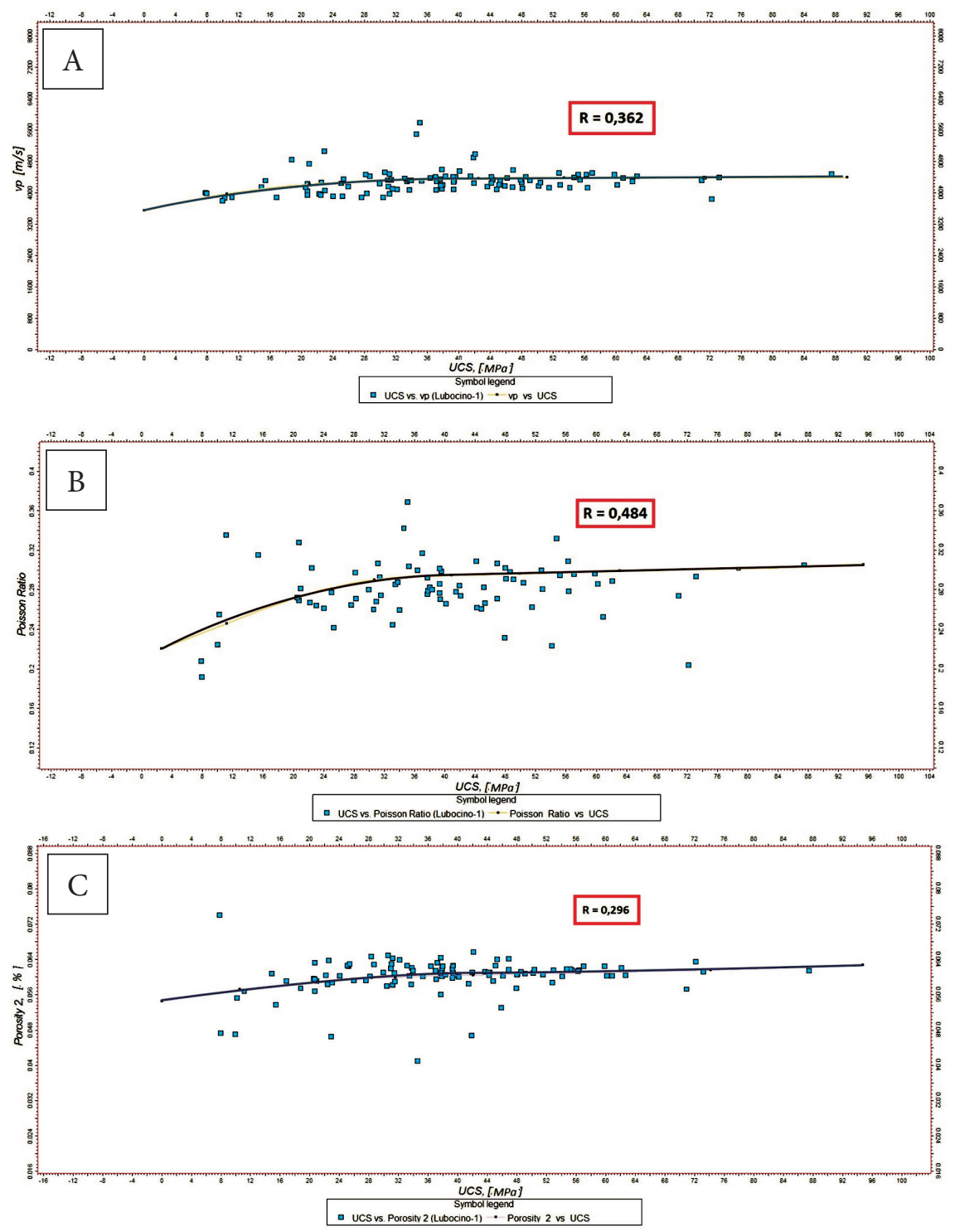

Fig. 10. Relationship between porosity (top), P-wave velocity (middle), Poisson's ratio (bottom) and UCS 
Based on the known patterns and determined relationships between the porosity, P-wave velocity, Poisson's ratio, and the UCS, a set of meta-attributes was created with a correlation coefficient of
0.522 . With the use of these meta-attributes the spatial distribution of the UCS was estimated in the 3D model. In Figure 11, we show spatial distribution of estimated UCS of lower Paleozoic shale formation.

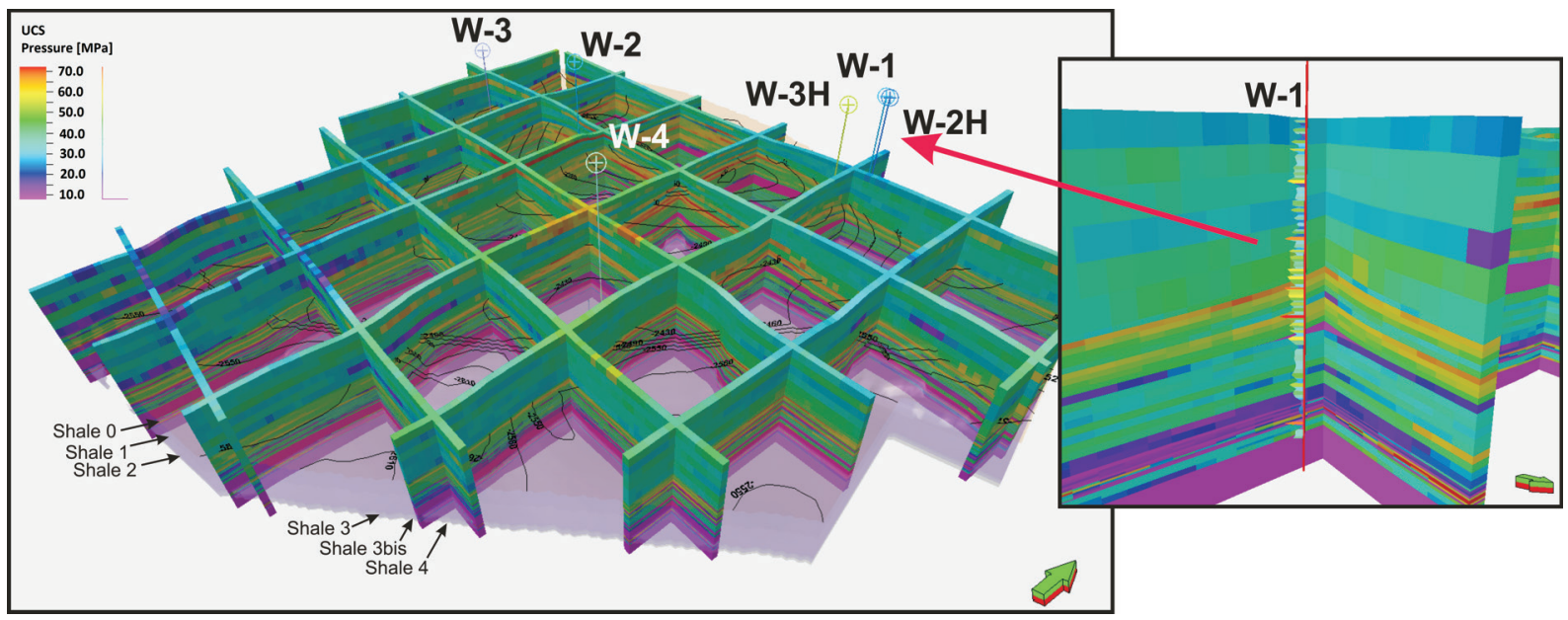

Fig. 11. Spatial distribution of estimated UCS in the entire model block (left) and in the vicinity of borehole W-1 with the UCS log obtained from compression tests on the drilled core samples (top right corner)

\section{Other mechanical parameters of the reservoir and the embedded model}

All the materials used in the model were assumed to fail by brittle fracture according to the Coulomb-Mohr failure criterion except for Zechstein salt, which due to its high plasticity exhibits different behavior. The salt deposits were assumed to behave according to the von Mises failure criterion, commonly used in ductile materials in which plastic behavior is driven by slippage of the crystal planes, in this case of salt crystals along the surface of maximum shear stress (Jeremic 1994). Other mechanical properties for the lithostratigraphic units of the overburden and the rocks surrounding the model were assigned according to the literature (Handing \& Hager 1957, Smith \& Faulkner 2010, Kwaśniewski \& Rodriguez-Oitaben 2012) and are listed in Table 1 and 2 .

Table 1

Set of calculated or assumed petrophysical and mechanical parameters of the rock materials of the Paleozoic shale formation, sideburden, and underburden

\begin{tabular}{|l|c|c|c|}
\hline \multicolumn{1}{|c|}{ Parameter [unit] } & $\begin{array}{c}\text { Paleozoic shale } \\
\text { formation } \\
\text { (sideburden) }\end{array}$ & $\begin{array}{c}\text { Paleozoic shale } \\
\text { formation } \\
\text { (reservoir) }\end{array}$ & $\begin{array}{c}\text { Paleozoic shale } \\
\text { formation } \\
\text { (underburden) }\end{array}$ \\
\hline Young modulus [GPa] & 25 & seismic derived & 25 \\
\hline Poisson's ratio & 0.35 & seismic derived & 0.35 \\
\hline Bulk denisty [g/cm ${ }^{3}$ ] & 2.42 & seismic derived & 2.42 \\
\hline Biot constant & 1 & 1 & 8 \\
\hline Porosity [\%] & 8 & seismic derived & 40 \\
\hline $\begin{array}{l}\text { Unconfined Compressive } \\
\text { Strength (UCS) }[\mathrm{MPa}]\end{array}$ & 40 & seismic derived & 30 \\
\hline Friction Angle $\left.{ }^{\circ}\right]$ & 30 & 30 & 5 \\
\hline Dilatation Angle $\left[{ }^{\circ}\right]$ & 5 & 5 & 1 \\
\hline
\end{tabular}


Table 2

Petrophysical and mechanical properties assumed for the overburden zones

\begin{tabular}{|c|c|c|c|c|c|c|}
\hline \multirow{2}{*}{ Parameter [unit] } & \multirow{2}{*}{$\begin{array}{c}\text { Cenozoic } \\
\text { (clays, sands, } \\
\text { gravels) }\end{array}$} & \multirow{2}{*}{$\begin{array}{l}\text { Cretaceous } \\
\text { (claystone) }\end{array}$} & \multirow{2}{*}{$\begin{array}{c}\text { Jurrasic } \\
\text { (mudstone) }\end{array}$} & \multicolumn{3}{|c|}{ Zechstein } \\
\hline & & & & Anhydrite & Salt & Dolomite \\
\hline Young modulus [GPa] & 0.1 & 1.5 & 5 & 55.5 & 1.4 & 83.81 \\
\hline Poisson's ratio & 0.3 & 0.31 & 0.15 & 0.26 & 0.44 & 0.2 \\
\hline Bulk denisty $\left[\mathrm{g} / \mathrm{cm}^{3}\right]$ & 1.9 & 2.6 & 2.27 & 2.85 & 2.17 & 2.82 \\
\hline Biot constant & 1 & 1 & 1 & 1 & 1 & 0.75 \\
\hline Porosity [\%] & 15 & 12 & 12 & 0 & 0 & 8 \\
\hline $\begin{array}{l}\text { Unconfined Compressive } \\
\text { Strength (UCS) [MPa] }\end{array}$ & 2.8 & 29 & 20 & 91.7 & - & 80 \\
\hline Friction Angle $\left[^{\circ}\right]$ & 30 & 30 & 22 & 29.4 & - & 45 \\
\hline Dilatation Angle $\left[^{\circ}\right]$ & 5 & 5 & 5 & 5 & - & 5 \\
\hline Cohesion $[\mathrm{MPa}]$ & - & - & - & - & 7.3 & - \\
\hline
\end{tabular}

\section{Pore pressure and boundary conditions}

Pore pressure. Due to the nature of pore pressure and its tendency to occur in abnormally high values in formations of low permeability such as shales, the study area was divided into shale and non-shale zones. In the shale zones the pore pressure was estimated with the use of Eaton's method, while in the remaining non-shale zones, pore pressure was assumed to be hydrostatic, with pore space connectivity between the various zones.

Eaton's pore pressure prediction method is one of the most widely used in the oil industry, based on Eaton's work in the Gulf of Mexico (Eaton 1975). Eaton's method estimates the pore pressure based on the ratio of the acoustic travel time in normally compacted sediments to the observed acoustic travel time. This method relies on creating a trend line based on data from a formation with a normal pressure regime, as well as knowledge of the overburden pressure gradient and normal pore pressure gradients of the area (Eaton 1975, Jędrzejowska-Tyczkowska et al. 2000, Sayers 2010). The pore pressure $P_{p}$ can be described as in Equation (2):

$P_{p}=\mathrm{OBG}-\left(\mathrm{OBG}-P_{n} G\right) \times\left(\Delta t_{\mathrm{norm}} / \Delta t\right)^{3}$

where OBG is the overburden stress gradient, $P_{n} G$ is the normal pore pressure gradient, $\Delta t$ norm is the travel time through the shale layer under normal hydrostatic pressure gradient, and $\Delta t$ is the travel time through the shale interval.
The pore pressure was estimated in boreholes $\mathrm{W}-1$ and $\mathrm{W}-2$, using the travel time to predict the pore pressure gradient in the geological formations of low permeability (see Equation (2)). In formations with pore space connectivity, the pore pressure was assumed to be hydrostatic and was calculated as follows:

$P_{h}=P_{p 0}+k\left(Z-Z_{0}\right)$

where $P_{h}$ is the hydrostatic pore pressure, $P_{p 0}$ is the pressure at the referenced true vertical depth, $k$ represents the pressure gradient, $Z$ is the true vertical depth, and $Z_{0}$ is the reference true vertical depth.

In Figure 12, we plot calculated pore pressure in the geological formation accordingly along boreholes W-1 (left side) and W-2 (right side). In the next step, the calculated pore pressure along boreholes $\mathrm{W}-1$ and $\mathrm{W}-2$ was used to estimate the spatial distribution of the pore pressure in the entire block model. In Figure 13, we display the 3D distribution of $P_{p}$ in the shale formation in the study area.

Both boreholes have zones with increased pore pressure (up to 425-475 bars; yellow-red areas in Figure 13) located within the shale interval that has high organic matter content. The calculated pore pressure in the block model was then used as the input data for the Visage geomechanical simulator. In the overburden and surrounding rocks, a normal pore pressure gradient of $0.1018 \mathrm{MPa} / \mathrm{m}$ was applied. 


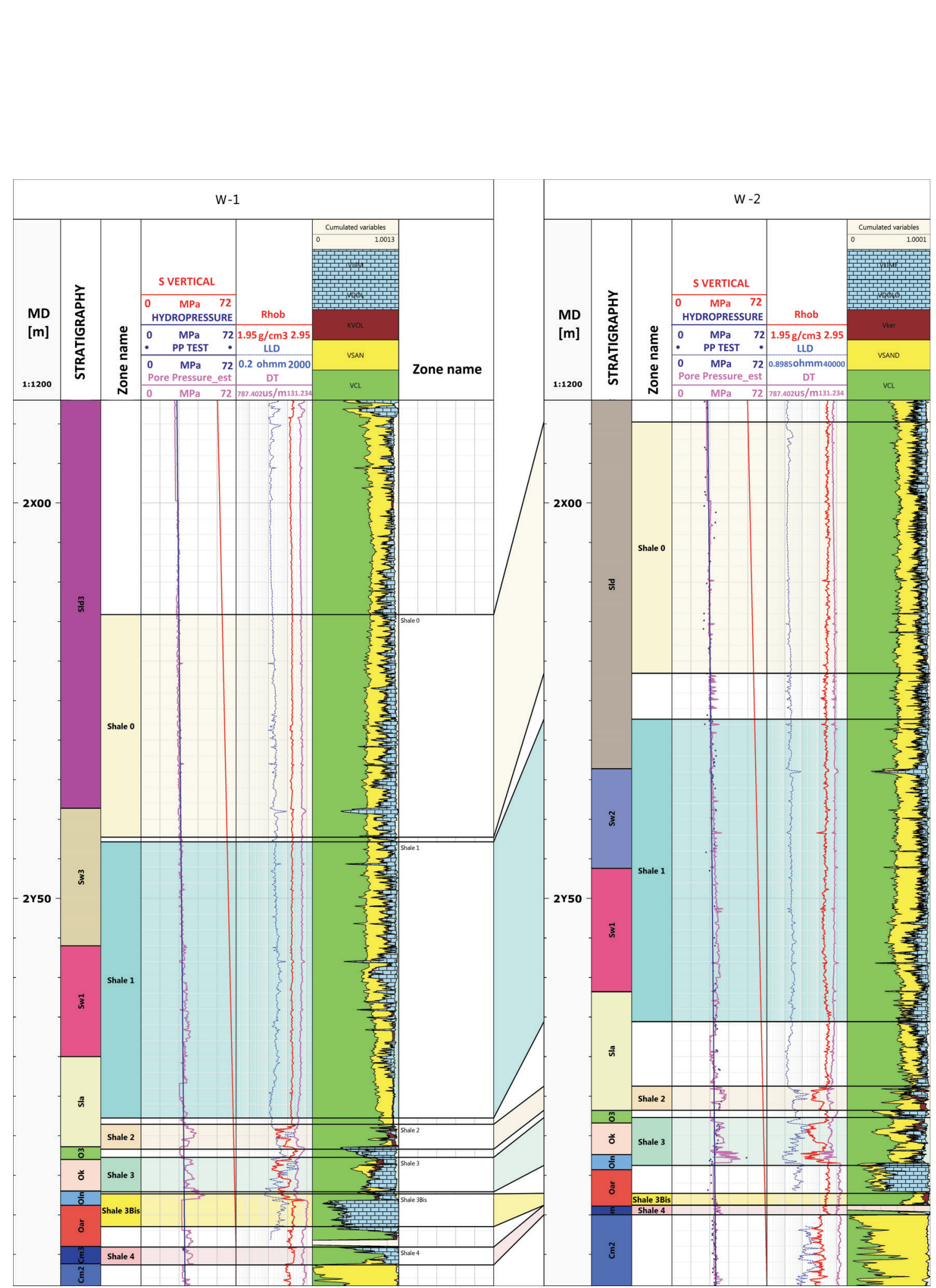

式

$\ddot{\mho}$

$\frac{\sqrt{2}}{\sqrt[3]{2}}$

$\frac{3}{3}$

ิิ)

$\check{\mho}$

ลิ

$\exists$

:

จิ

这

ते ईँ

ปั

$\because \frac{5}{5}$

홍ำ

$\pi \cdot \frac{1}{2}$

32

㝴

式氙

젼

3 제

ڤั

$\frac{1}{5}$

डे

$\equiv \frac{2}{2}$

ปे

离 $\frac{1}{3}$

공

o 5

च

ปั

$\stackrel{2}{0}$

苋这

है :

氜

究

$\frac{2}{2} \cdot \frac{2}{2}$

ก $\frac{5}{5}$

मे 


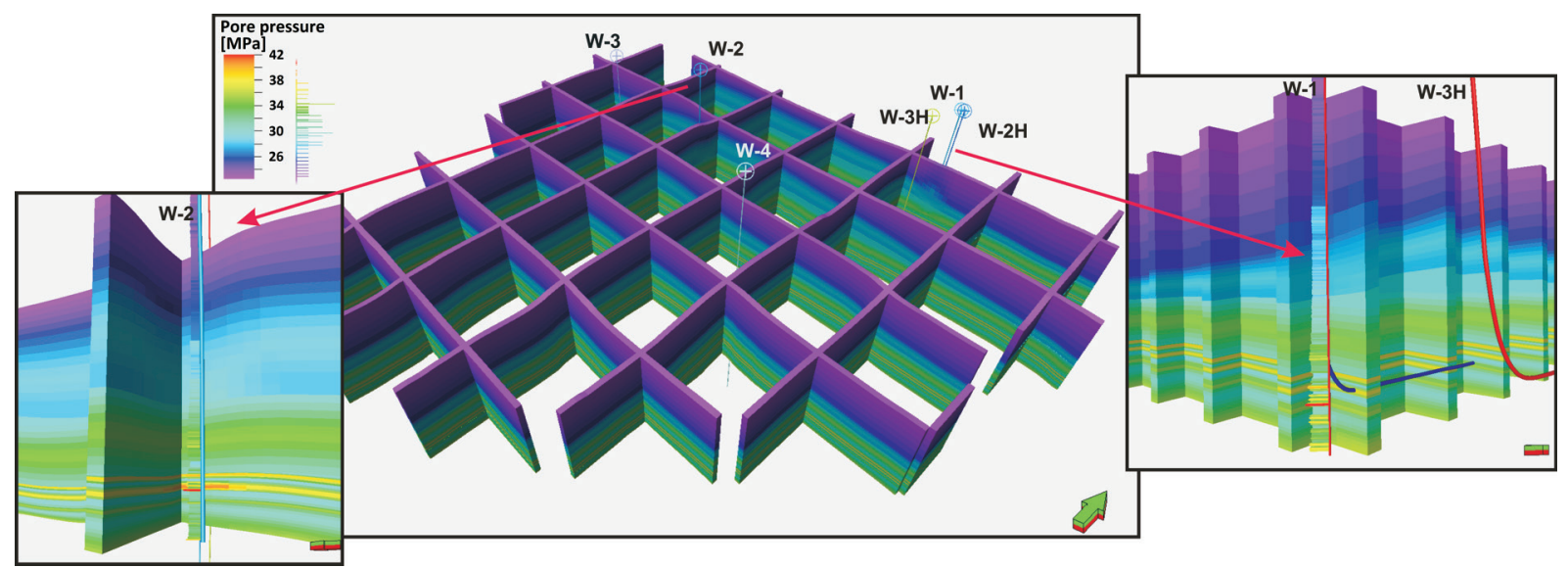

Fig. 13. Spatial distribution of pore pressure in the block model (middle panel) and around boreholes W-1 (right panel) and W-2 (left panel). The well profiles show a zone with increased pore pressure, up to 42.5-47.5 MPa (yellow-red shades in the 3D model)

Boundary conditions. The boundary conditions were determined by the gradient and general direction of the horizontal stresses defined on the basis of preliminary analysis of the image log from borehole W-1. Based on the borehole log, induced fractures exhibit a general azimuth trend of $\sim 25^{\circ}$. Due to a lack of relevant data, the gradient of the minimum horizontal stress $\sigma_{h}$, was estimated based on the results of a leak-off test conducted in a borehole approximately $30 \mathrm{~km}$ north-east of the study area. The leak-off test provides the approximate magnitude of $\sigma_{h}$, which in the petroleum industry is equated with the fracture closure pressure $P_{c}$ - one of the parameters determined in the test. Based on a single leak-off test, the minimum horizontal stress gradient was calculated.

The anisotropy between $\sigma_{H}$ and $\sigma_{h}$, the maximum and minimum horizontal stresses, was determined using the fast and slow shear waves recorded in borehole $\mathrm{W}-1$, which split when entering the anisotropic medium. The anisotropy, defined as the ratio between the slow and fast shear waves, was close to 1.0 in the study area; therefore, we assumed quasi-isotropic conditions $\left(\sigma_{H} / \sigma_{h}=1.01\right)$ (see Tab. 3). In Figure 14, we plot fast and slow shear wave ratio versus depth in the lower Paleozoic shale formation.

\section{Table 3}

Boundary conditions assumed for the model

\begin{tabular}{|l|c|}
\hline$\sigma_{h}$ gradient $[\mathrm{MPa} / \mathrm{m}]$ & 0.0236 \\
\hline $\boldsymbol{\sigma}_{H} / \boldsymbol{\sigma}_{h}$ ratio & 1.01000 \\
\hline$\sigma_{H}$ azimuth & 25.0000 \\
\hline
\end{tabular}

The developed 3D models of particular petrophysical, elastic and strength properties as well as the model of pore pressure and determined boundary conditions constituted a set of input data for the geomechanical simulation.

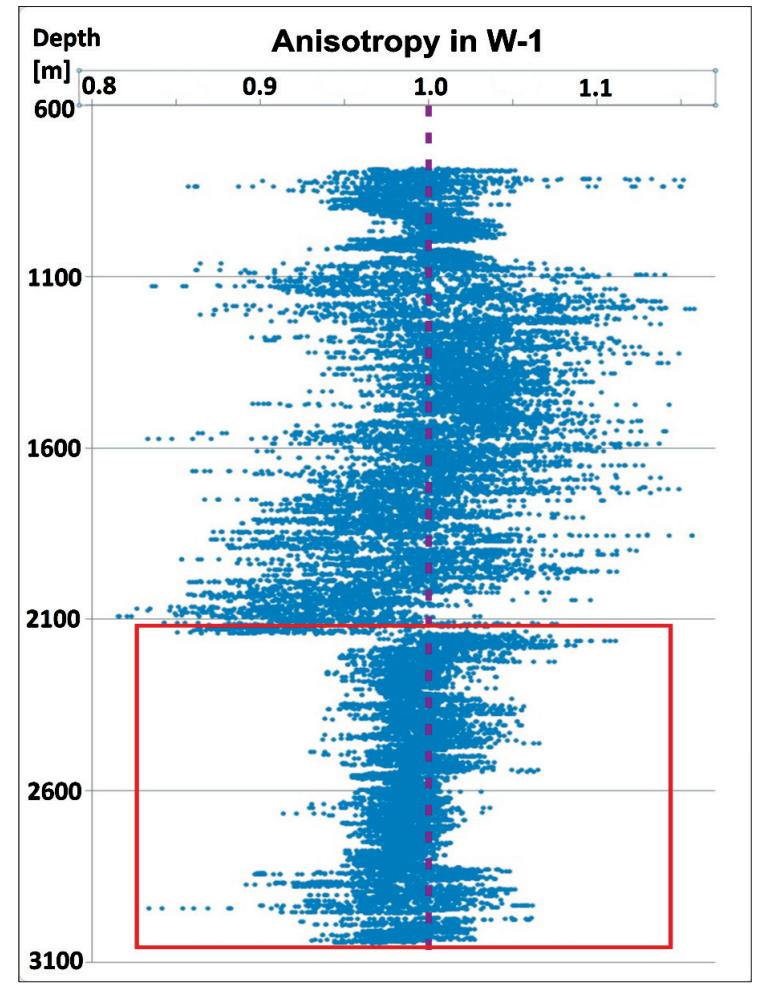

Fig. 14. Anisotropy in borehole W-1 calculated from the fast and slow shear waves recorded in the shale formation (red rectangle)

\section{Simulation results}

From the geomechanical modelling we obtained the distribution of both magnitude and directions of 
the principal stresses - the vertical stress $\sigma_{V}$ and the maximum and minimum horizontal stresses $\sigma_{h}$ and $\sigma_{H}$, respectively, acting on the shale formation of the lower Paleozoic age and the surrounding rocks.

The geomechanical simulation results indicate that the normal stress regime prevails in the analyzed shale formation, although intervals with a strike slip regime are also observed. This type of tectonic regime should have a positive influence on hydraulic fracturing work. The $\sigma_{h}$ direction is
NEE-SWW, which at the same time is the preferential direction of horizontal section of the borehole. Hydraulic fractures generated due to stimulation techniques are expected to propagate along the direction perpendicular to $\sigma_{h}$.

In terms of the elastic properties that are crucial for shale formation stimulation treatment, the horizontal wells (Fig. 15A, B) are placed in a favorable location from the hydraulic fracturing effectiveness point of view.
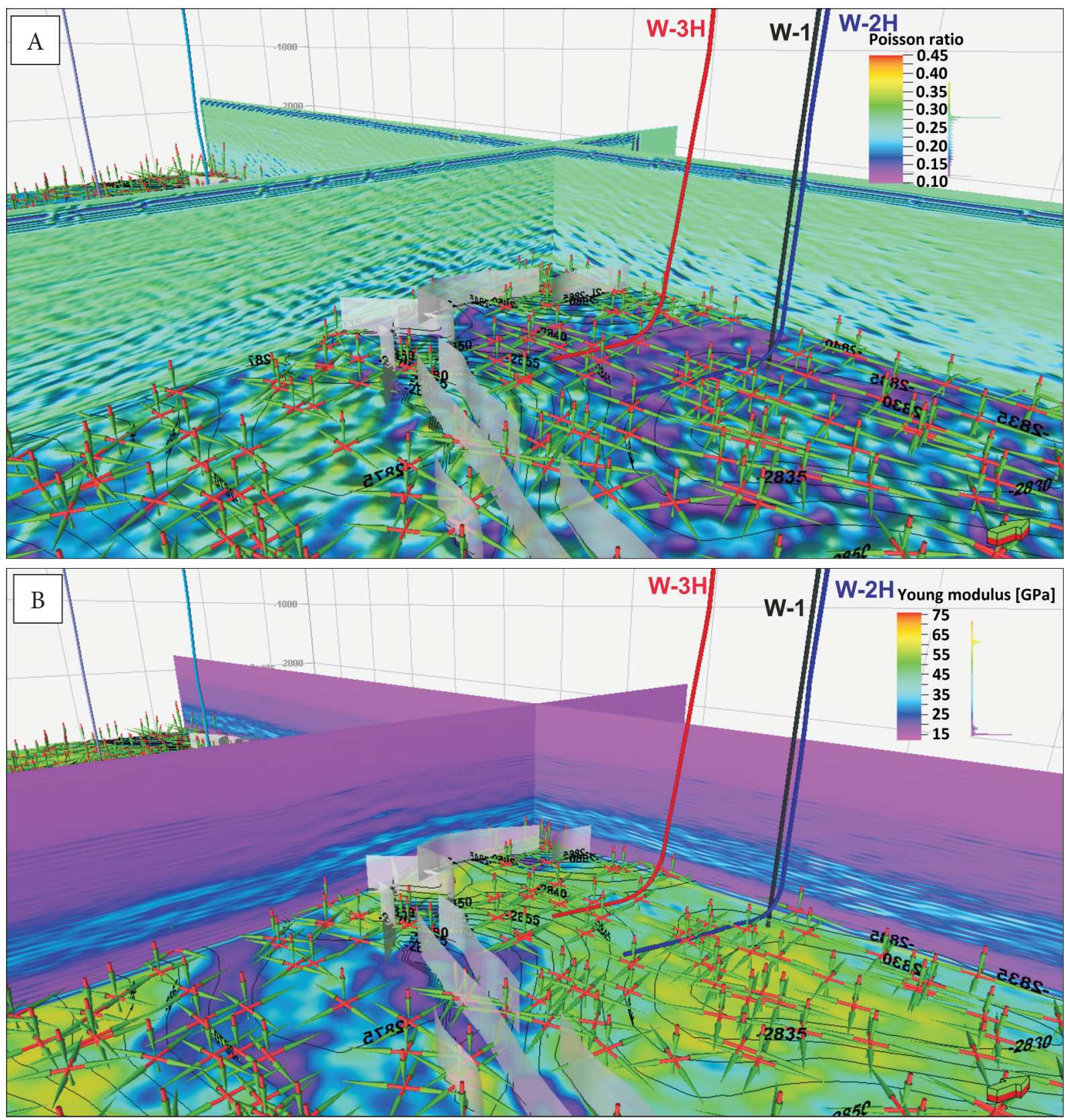

Fig. 15. Distribution of principal stresses in the shale formation in the vicinity of the horizontal wells in the study area with visualization of the distribution of Poisson's ratio (A) and Young's modulus (B) 
In the vicinity of both wells the shale formation is stiffer, with a Young's modulus of 30-40 GPa, and less plastic (Poisson's ratio $\sim 0.30$ ). The optimal area for stimulation treatment is located towards NW from the W-2 and W-3 boreholes and between these wells with a Young's modulus of 50-60 GPa and Poisson's ratio $<0.23$.

In Figure 15A and B we show that the horizontal well sections deviate slightly from the direction of minimum horizontal stress, which in petroleum engineering is considered to be the optimal direction (Plumb et al. 2000). Consequently, both the location of the boreholes as well as the deviation of the horizontal sections from the direction of the minimum horizontal stress could have affected low effectiveness of the hydraulic fracturing treatment performed in the $\mathrm{W}-2 \mathrm{H}$ borehole. However, by changing the trajectory of the horizontal section of the well, by approximately $20^{\circ}$ towards south, so that it follows the direction of the minimum horizontal stress, not only do the drilling conditions improve but the optimal brittle-ductile properties of the rock for fracturing would also be reached.

Around major geological structures and discontinuities, a reorientation of horizontal stresses usually occurs (Zoback 2010). The distribution of stresses calculated in the Visage geo mechanical simulator covers the entire model and accounts for the stress perturbation in the vicinity of the faults. In some regions of the model, particularly where the rock in the fault zone was more rigid than the surrounding rocks (possibly due to the sealing of fault zone with stiffer rock material or mineralization), the direction of $\sigma_{H}$ was parallel to the discontinuity (see Fig. 16). However, in the fault zones weakened by the failure, the direction of $\sigma_{H}$ was perpendicular to the faults. Finally, in the fault zones where no rock strength contrast was present, no perturbation in the direction of the horizontal stresses was observed (Stephansson 2003).

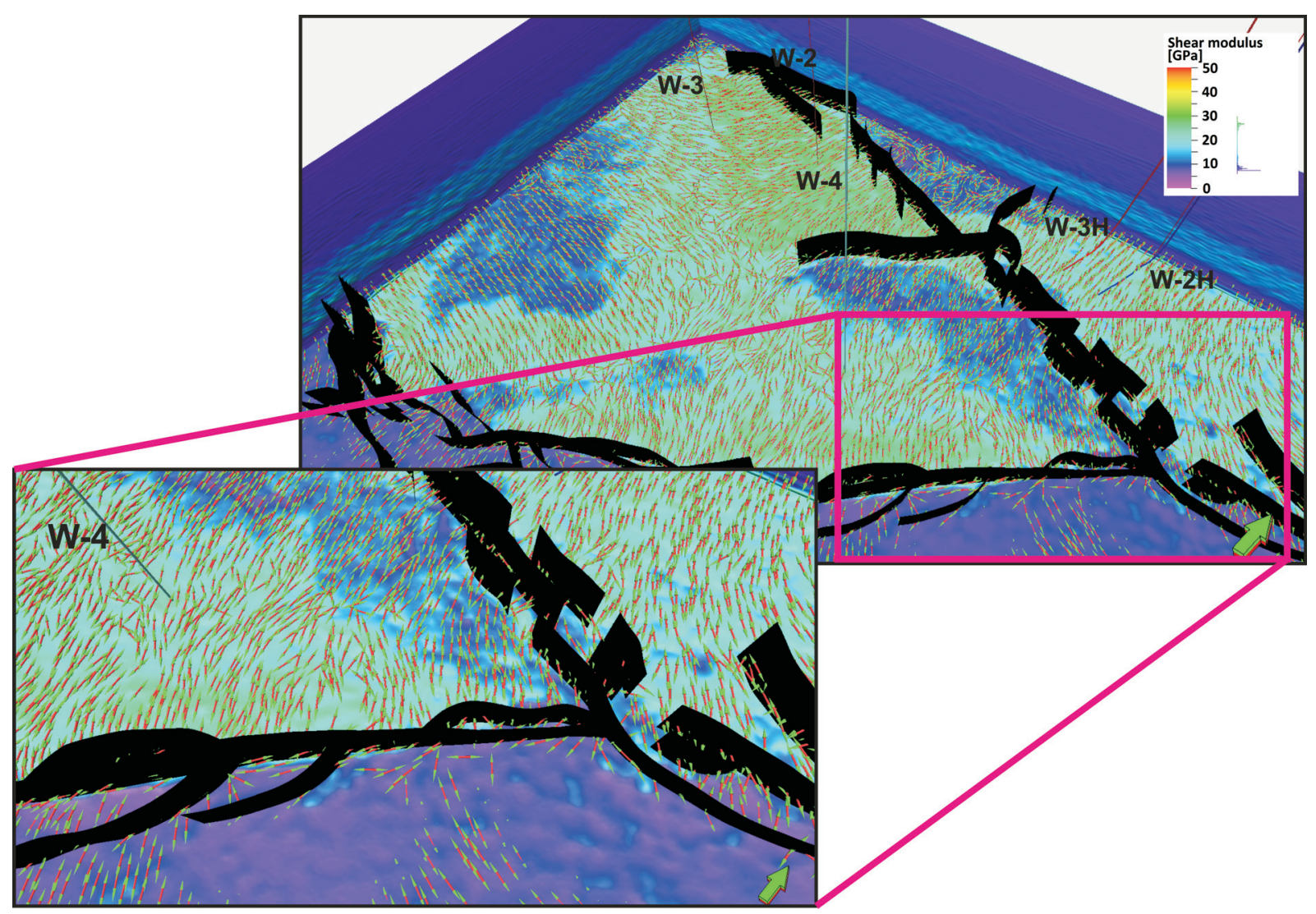

Fig. 16. Distribution of principal stresses in the shale formation (top), and enlarged panel showing the dislocation zone where reorientation of the maximum horizontal stress $\sigma H$ in the vicinity of fault can be observed (bottom) 
In the vertical stress profile illustrated in Figure 17, a zone with increased pore pressure can be observed (purple-dark-blue areas) which provides additional support to the overlaying rock load and therefore decreases the effective vertical stress. The difference in the magnitude between the horizontal stresses is subtle as almost isotropic conditions were defined in the simulation. The magnitude of $\sigma_{h}$ and $\sigma_{H}$, presented in Figure 18A and $\mathrm{B}$, respectively, allows for constraining a safe mud weight window when designing drilling and determine the pressure level of injected fluid required to frack the formation during the reservoir stimulation process. In Figure 18A spatial distribution of $\sigma_{h}$ indicates that to fracture the formation targeted with horizontal section of $\mathrm{W}-2 \mathrm{H}$ and $\mathrm{W}-3 \mathrm{H}$ boreholes, the pressure of the injected fluid needs to exceed 110-115 bar.

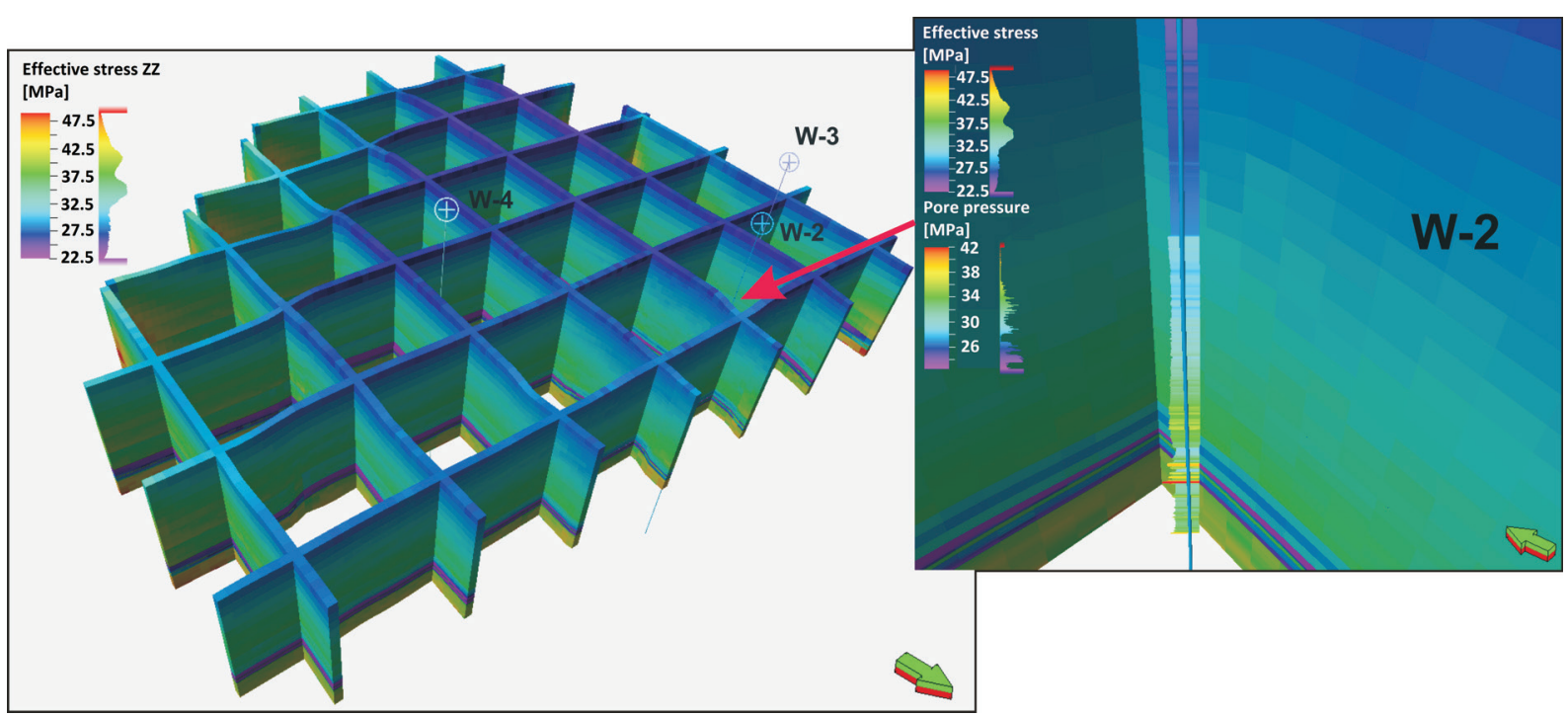

Fig. 17. Effective vertical stress distribution in the block model (left) and enlarged image of the shale formation exhibiting the overpressure marked in purple-dark-blue with visualization of the pore pressure log in W-2 borehole (right panel)

The distribution of principal stresses obtained in this study can serve as a guideline for drilling engineers by taking into account preferential well placement, the optimal direction of the horizontal section of the borehole as well as being aware of areas more suitable for hydraulic fracturing, controlled by the elastic properties and acting stresses. As mentioned above, elements strongly influence the efficiency of the stimulation treatment of unconventional shale formation, they should be determined with caution and supported with a thorough geomechanical background.

As with every numerical model, we are also confronted with uncertainty resulting from many reasons in the presented mechanical model of lower Paleozoic shale formation. Generally, the geomechanical modelling method presented in the study employs a wide range of data like laboratory measurements, well log data, reservoir engineering data, seismic data, based on which parametric models of petrophysical, elastic and strength properties are developed. Although the importance of geomechanical parameters is becoming increasingly appreciated, some of the parametric models were not calibrated due to a lack of data. Not to mention that every measurement method is encumbered with an error. Another element affecting the uncertainty of the developed model is the simplification of the stratigraphic divisions of the overburden which, due to a lack of data, were characterized mainly based on assumptions founded on literature studies. All these elements build up the uncertainty which with the upcoming new data and interpretation can be reduced making the model closer to reality. 

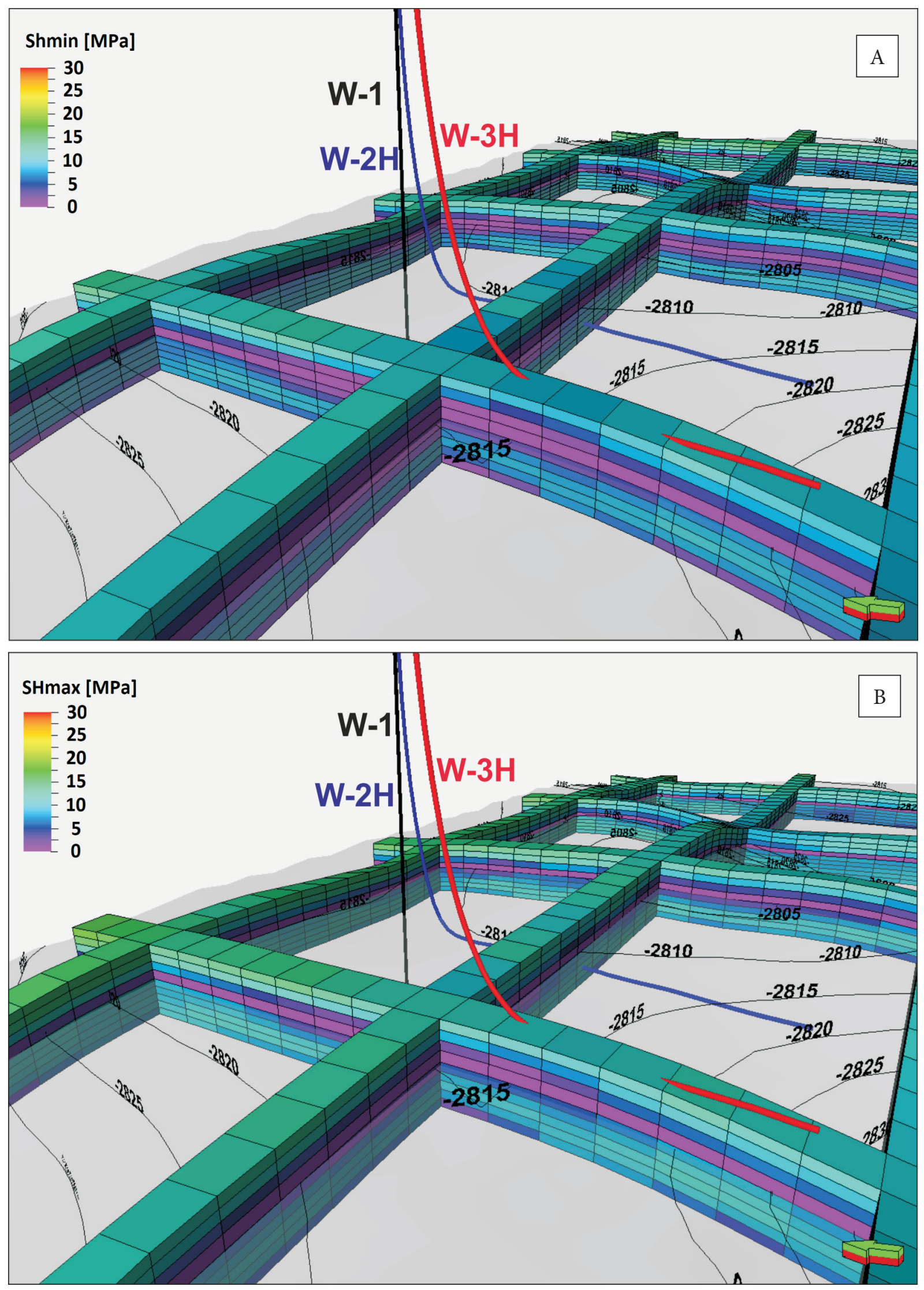

Fig. 18. Fence diagram presenting the spatial distribution of $\sigma h(A)$ and $\sigma H(B)$ around the horizontal wells $L-2 H$ and $L-3 H$ drilled through the shale layer containing the highest hydrocarbons potential 


\section{CONCLUSIONS}

Geomechanical modelling is a method extending the characterization of unconventional geological formations, which require stimulation treatment to obtain an economic level of hydrocarbons production. The use of diverse types of data and its processing results is essential for mechanical model, hence it is necessary to carry it out as a part of a broader, interdisciplinary research.

3D spatial visualization of the stresses, pore pressure, and mechanical properties of the rock helps us understand the reservoir response to drilling, stimulation treatment, and possible hydrocarbons production, thus contributing to the optimization of these processes and prediction of the reservoir's response to human interference. The results of the geomechanical modelling allows us to determine favorable well placement for hydraulic fracturing, optimize the direction of horizontal section of the borehole and the parameters of the stimulation treatment.

The obtained stress distribution indicates that the normal stress regime prevails in the analyzed shale interval, with the ratio between principal stresses being $\sigma_{v}>\sigma_{H}>\sigma_{h}$. The $\sigma_{h}$ direction is NEE-SWW, which at the same time is the preferential direction of horizontal section of the borehole. Hydraulic fractures generated due to stimulation techniques are expected to propagate along the direction perpendicular to $\sigma_{h}$.

Based on the spatial distribution of the elastic properties, zones more suitable for hydraulic fracturing were determined. The most optimal area for stimulation treatment is located towards NW from the W-2 and W-3 boreholes and between these wells, with a Young's modulus of 50-60 GPa and Poisson's ratio $<0.23$.

By means of the modification of the trajectory of the horizontal section of the well by approximately $20^{\circ}$ towards south, so that it follows the direction of the minimum horizontal stress, not only do the drilling conditions improve but the optimal brittle-ductile properties of the rock for fracturing would also be obtained.

A spatial distribution of $\sigma_{h}$ indicates that to fracture the formation targeted with horizontal section of $\mathrm{W}-2 \mathrm{H}$ and $\mathrm{W}-3 \mathrm{H}$ boreholes, the pressure of the injected fluid needs to exceed 110-15 bar.
Finally, the observed presence of a high-pressure zone in the potential reservoir shale interval not only suggests the need to take special precautions while drilling through this zone, but also raises the prospect for potential exploitation in the area of the study.

Since exploration of hydrocarbons tends to focus on geological formation of unconventional characteristics, e.g. shale, tight gas or CBM and reservoirs of more challenging accessibility, requiring stimulation treatment, geomechanical modelling appears to be becoming increasingly common in industry practice.

This work was supported by the Ministry of Science and Higher Education fund allocated with the decision 202014/E-271/S/2015. The Authors would like to thank the Schlumberger company for providing the software used in this study.

\section{REFERENCES}

Akbar Ali A.H., Brown T., Delgado R., Lee D., Plumb D., Smirnov N., Marsden R., Prado-Velarde E., Ramsey L., Spooner D., Stone T. \& Stouffer T., 2008. Watching Rocks Change - Mechanical Earth Modeling. Oilfield Review, 15, 2, 22-39.

Geological characteristics of the basin, 2012. [in:] Assessment of Shale Gas and Shale Oil resources of the Lower Paleozoic Baltic-Podlasie-Lublin Basin in Poland. First Report, Polish Geological Institute - National Research Institute, Warsaw, 9-15, [on-line:] http://www.pgi.gov.pl/en/ docman-dokumenty-pig-pib/docman/aktualnosci-2012/ zasoby-gazu/769-raport-en/file.html [access: 21.05.2017].

Bjørlykke K., Høeg K. \& Haque Mondol M., 2010. Introduction to Geomechanics: Stress and Strain in Sedimentary Basins. [in:] Bjørlykke K. (ed.), Petroleum Geoscience: From sedimentary Environments to Rock Physics, Springer, Heidelberg, 281-298.

Bruyelle J. \& Guérillot D.R., 2014. An accurate volumetric calculation method for estimating original hydrocarbons in place for oil and gas shales including adsorbed gas using high-resolution geological model. [in:] International Petroleum Technology Conference 2014 (IPTC 2014): Unlocking Energy Through Innovation, Technology and Capability, Doha, Qatar, 19-22 January 2014, Society of Petroleum Engineers, 1-12.

Butel N., Hossack A. \& Kizi M., 2014. Prediction of in situ rock strength using sonic velocity. [in:] Aziz N., Kininmonth B., Nemcik J., Black D., Hoelle J. \& Cunbulat I., Proceedings of the 2014 Coal Operators' Conference. Coal 2014: Australian Coal Operators' Conference 2014, Wollongong, New South Wales, Australia, 12-14 February, 2014, 89-102.

Chang C., Zoback M.D. \& Khaksar A., 2006. Empirical relations between rock strength and physical properties in sedimentary rocks. Journal of Petroleum Science, 51, 3, $223-237$. 
Cordon H.R.A. \& van Hoogstraten R., 1995. Key Issues for Successful Industrial Neural Network Applications: an Application in Geology. [in:] Braspenning P.J., Thuijsman F. \& Weijters A.J.M.M. (eds.), Artificial Neural Networks: An Introduction to ANN Theory and Practice, Springer, Heidelberg, 235-245.

Eaton B.A., 1975. The equation for geopressure prediction from well logs. [in:] Fall Meeting of the Society of Petroleum Engineers of AIME, 28 September - 1 October, Dallas, Texas, SPE-5544-MS, Society of Petroleum Engineers.

Encyclopædia Britannica, https://kids.britannica.com/students/assembly/view/143546 [access: 23.06.2017].

Fjær E., Holt R.M., Horsrud P., Raaen A.M. \& Risnes, R., 2008. Rock Mechanics and Rock Acoustics. [in:] Petroleum Related Rock Mechanics, Elsevier, Oxford, 192-195.

Handin J. \& Hager R.V., 1957. Experimental deformation of sedimentary rocks under confining pressure: Tests at room temperature on dry samples. Bulletin of the American Association of Petroleum Geologists, 41, 1-51.

Heege H., Zijp M.H.A.A. \& Nelskamp S., 2015. Sweet spot for hydraulic fracturing and oil org as production in underexplored shales using key performance indicators: example of the Posidonia Shale Formation in the Nederlands. [in:] International Petroleum Technology Conference, 6-9 December, Doha, Qatar, IPTC-18348-MS. DOI: 10.2523/IPTC-18348-MS.

Herwanger J. \& Koutsabeloulis N., 2011. Building Reservoir Geomechanical Model. [in:] Seismic Geomechanics: How to Build and Calibrate Geomechanical Models using $3 D$ and $4 D$ Seismic Data, EAGE Publications, Houten, 17-37.

Jarosiński M., Beekman F., Bada G. \& Cloetingh S., 2006. Redistribution of recent collision push and ridge push in Central Europe: insights from FEM modelling. Geophysical Journal International, 167, 2, 860-880.

Jeremic M.L., 1994. Stress analysis of mine structures. [in:] Rock Mechanics in Salt Mining, A.A. Balkema, Rotterdam, Brookfield, VT, 299-322.

Jędrzejowska-Tyczkowska H., Żukowska K., Misiarz P., Bartoń R. \& Żuławiński K., 2000. Prediction of overpressure zones in the geological formations with the use of seismic data. Nafta-Gaz, 12, 689-706.

Jędrzejowska-Tyczkowska H., 2003. Sejsmiczne konsystentne estymatory złoża weglowodorów. Prace Instytutu Górnictwa Naftowego i Gazownictwa, 123, IGNiG, Kraków.

Jędrzejowska-Tyczkowska H. \& Słota-Valim M., 2012. Mechaniczny model Ziemi jako nowy i konieczny warunek sukcesu w poszukiwaniach i eksploatacji niekonwencjonalnych złóż węglowodorów. Nafta-Gaz, 68, $6,329-340$

King G.E., 2012. Hydraulic Fracturing 101: What every Representative, Environmentalist, Regulator, Reporter, Investor, University Researcher, Neighbor and Engineer Should Know About Estimating Frack Risk and Improving Frack Performance in Unconventional Gas and Oil Wells. [in:] SPE Hydraulic Fracturing Technology Conference, 6-8 February, The Woodlands, Texas, USA, SPE152596-MS, Society of Petroleum Engineers.

Kowalska-Włodarczyk M. \& Darłak B., 2011. Modele stochastyczne wybranych parametrów jako wsparcie konstruowania modeli geologicznych przy użyciu ANN i Fuzzy Logic. Nafta-Gaz, 67, 1, 7-13.
Kwaśniewski M. \& Rodriguez-Oitaben, P., 2012. Study on the dilatancy angle of rocks in the pre-failure domain. [in:] Qian Q. \& Zhou Y. (eds.), Harmonizing Rock Engineering and the Environment, Taylor and Francis Group, London, 681-686.

Mashinskii E.I., 2003. Differences between static and dynamic elastic moduli of rocks: Physical causes. Russian Geology and Geophysics, 44, 9, 953-959.

Plumb R., Edwards S., Pidcock G., Lee D. \& Stacey B., 2000. The Mechanical Earth Model Concept and Its Application to High-Risk Well Construction Projects. [in:] IADC/SPE Drilling Conference, 23-25 February, New Orleans, Louisiana, SPE-59128-MS, Society of Petroleum Engineers. DOI: 10.2118/59128-MS.

Poprawa P., 2010. Potencjał występowania złóż gazu ziemnego w łupkach dolnego paleozoiku w basenie bałtyckim i lubelsko-podlaskim. Przegląd Geologiczny, 58, 3, 226249.

Pyrcz M.J. \& Deutsch C.V., 2014. Preliminary Mapping Concepts. [in:] Geostatistical Reservoir Modeling, Oxford University Press, New York, 118-122.

Romero A.M. \& Philp R.P., 2012. Organic geochemistry of the Woodford Shale, southeastern Oklahoma: How variable can shales be? AAPG Bulletin, 96, 3, 493-517.

Sayers C., 2010. Pore pressure. [in:] Geophysics Under Stress: Geomechanical Applications of Seismic and Borehole Acoustic Waves, 2010 Distinguished Instructor Short Course, Distinguished Instructor Series, 13, Society of Exploration Geophysics and European Association of Geoscientist and Engineers, 19-44.

Slatt R.M., 2011. Important geological properties of unconventional resource shales. Central European Journal of Geosciences, 3, 4, 435-448.

Słota-Valim M., 2015. Static and dynamic elastic properties, the cause of the difference and conversion methods case study. Nafta-Gaz, 11, 816-826.

Smith S.A.F. \& Faulkner D.R., 2010. Laboratory measurements of the frictional properties of the Zuccale low-angle normal fault, Elba Island, Italy. Journal of Geophysical Research, 115. DOI: 10.1029/2008JB006274.

Sonmez H., Gokceoglu C., Nefeslioglu H.A. \& Kayabasi A., 2006. Estimation of rock modulus: for intact rocks with an artificial neural network and for rock masses with the new empirical equation. Rock Mechanics and Mining Sciences, 43, 2, 224-235.

Sowiżdżał K., 2012. Modelowanie 3D. Geostatystyczne, facjalne i parametryczne modelowanie 3D w odniesieniu do niekonwencjonalnych złóż gazu ziemnego. Prace $\mathrm{Na}$ ukowe Instytutu Nafty i Gazu, 183, 135-150.

Stephansson O., 2003. Estimation of virgin state of stress and determination of final rock stress model. [in:] Sugawara K., Obara Y. \& Sato A. (eds.), Rock Stress '03: Proceedings of the Second International Symposium on Rock Stress, Kumamoto, Japan, 4-6 November 2003 Rock Stress '03: Proceedings of the Second International Symposium on Rock Stress RS Kumamoto, AA. Balkema Publishers, Tokyo, 49-56.

Vecoli M. \& Samuelsson J., 2001. Quantitative evaluation of microplankton paleobiogeography in the OrdovicianEarly Silurian of the northern Trans European Suture Zone: implications for the timing of the Avalonia-Baltica collision. Review of Paleobotany and Palynology, 115, $1-2,43-68$. 
Verniers J., Maletz J., Kř́íz J., Žigaitė Ž., Paris F., Schönlaub P.H \& Wrona R., 2008. Silurian. [in:] McCann T. (ed.), The Geology of Central Europe. Volume 1: Precambrian and Paleozoic, Geological Society, London, 249-256. DOI: 10.1144/CEV1P.6.
Zoback M.D., 2010. Stress fields - from tectonic plates to reservoir around the world. [in:] Reservoir Geomechanics, Cambridge University Press, Cambridge, 266-297.

Zou C., 2013. Unconventional Petroleum Geology. $1^{\text {st }}$ ed. Elsevier, Burlington. 